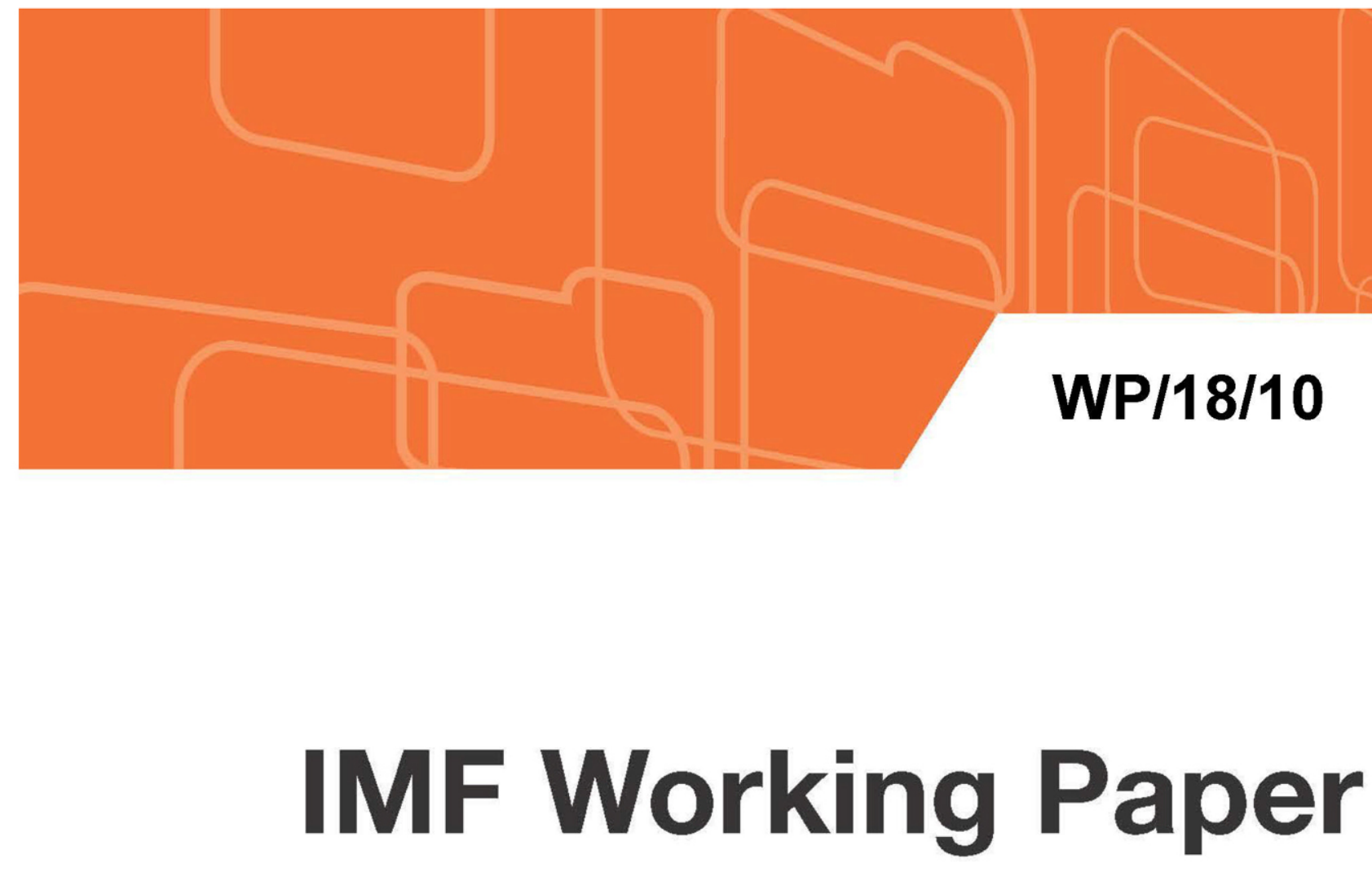

\title{
Economic Convergence in the Euro Area: Coming Together or Drifting Apart?
}

by Jeffrey Franks, Bergljot Barkbu, Rodolphe Blavy, William Oman, and Hanni Schoelermann

IMF Working Papers describe research in progress by the author(s) and are published to elicit comments and to encourage debate. The views expressed in IMF Working Papers are those of the author(s) and do not necessarily represent the views of the IMF, its Executive Board, or IMF management. 


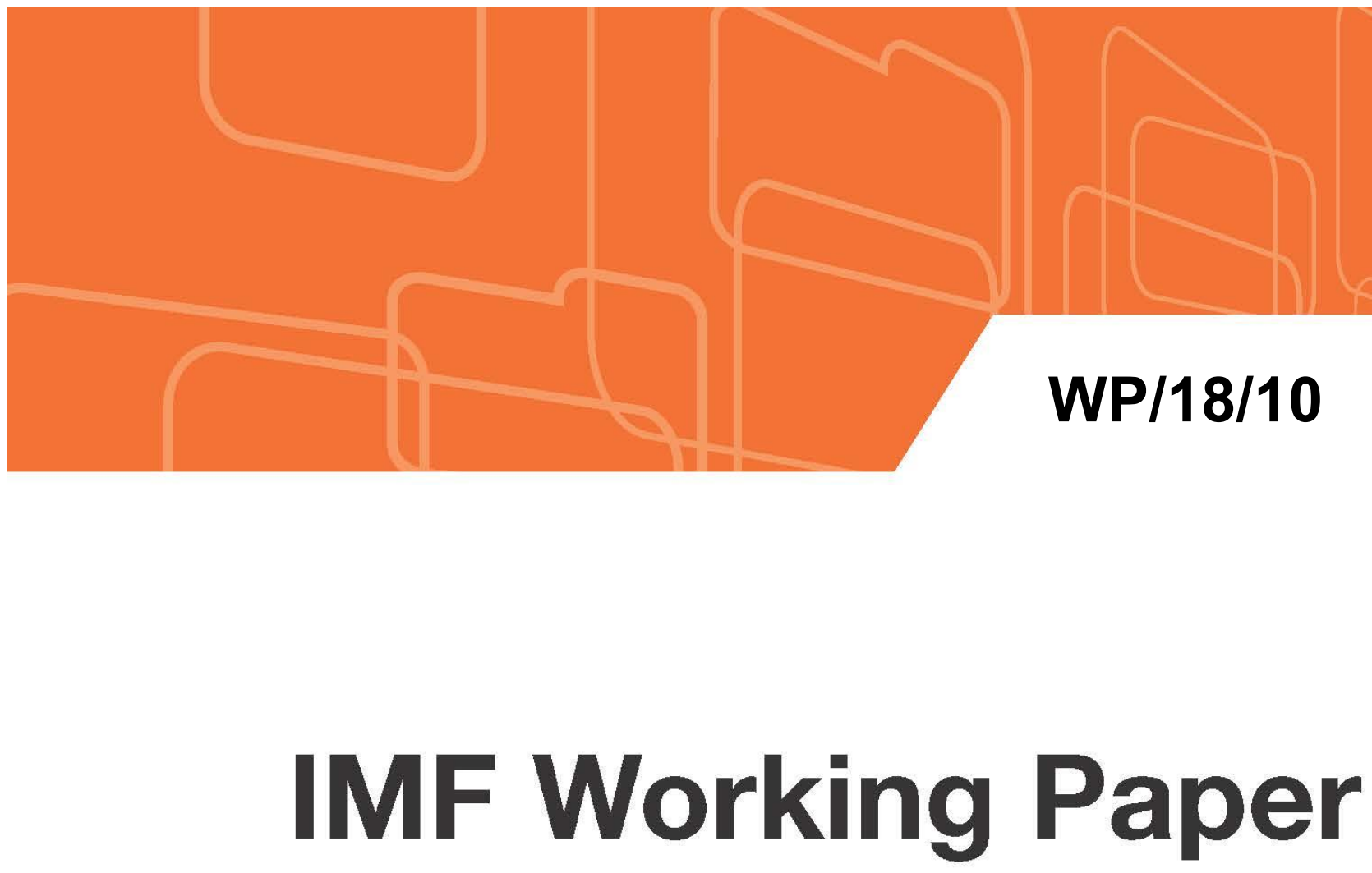

\section{Economic Convergence in the Euro Area: Coming Together or Drifting Apart?}

by Jeffrey Franks, Bergljot Barkbu, Rodolphe Blavy, William Oman, and Hanni Schoelermann

IMF Working Papers describe research in progress by the author(s) and are published to elicit comments and to encourage debate. The views expressed in IMF Working Papers are those of the author(s) and do not necessarily represent the views of the IMF, its Executive Board, or IMF management. 


\title{
IMF Working Paper
}

European Department

Economic Convergence in the Euro Area:

Coming Together or Drifting Apart?

\section{Prepared by Jeffrey Franks, Bergljot Barkbu, Rodolphe Blavy, William Oman, and Hanni Schoelermann ${ }^{1}$}

Authorized for distribution by Mahmood Pradhan

January 2018

\section{IMF Working Papers describe research in progress by the author(s) and are published to elicit comments and to encourage debate. The views expressed in IMF Working Papers are those of the author(s) and do not necessarily represent the views of the IMF, its Executive Board, or IMF management.}

\begin{abstract}
We examine economic convergence among euro area countries on multiple dimensions. While there was nominal convergence of inflation and interest rates, real convergence of per capita income levels has not occurred among the original euro area members since the advent of the common currency. Income convergence stagnated in the early years of the common currency and has reversed in the wake of the global economic crisis. New euro area members, in contrast, have seen real income convergence. Business cycles became more synchronized, but the amplitude of those cycles diverged. Financial cycles showed a similar pattern: sychronizing more over time, but with divergent amplitudes. Income convergence requires reforms boosting productivity growth in lagging countries, while cyclical and financial convergence can be enhanced by measures to improve national and euro area fiscal policies, together with steps to deepen the single market.
\end{abstract}

\footnotetext{
${ }^{1}$ The authors would like to thank for their comments Shekhar Aiyar, Marco Buti, Servaas Deroose, Ettore Dorrucci, Christian Ebeke, Gabriele Giudice, Jesper Hanson, Paul Hiebert, Huidan Lin, Klaus Masuch, Christian Mumssen, and James Roaf.
} 
JEL Classification Numbers: E32, F15, F36, F45, O47

Keywords: Convergence, business cycles, financial cycles, synchronization, Economic and Monetary Union, euro area, Optimum Currency Area

Authors’ E-Mail Addresses: jfranks@,imf.org, bbarkbu@,imf.org, rblavy@imf.org, woman@imf.org, hschoelermann@imf.org 
Abstract. .$\underline{2}$

I. Introduction $\underline{5}$

II. What Kind of Convergence Does the Euro Area Need? $\underline{6}$

III. Have Euro Area Countries Converged? ............................................................... $\underline{8}$

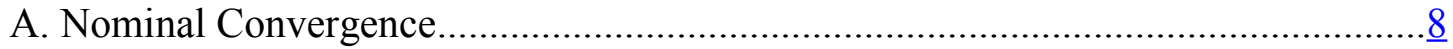

B. Real Convergence: Income, Unemployment, and Productivity ...........................11

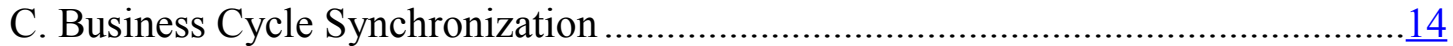

D. Financial Cycle Synchronization and Capital Flows …..................................

IV. Adjustment Mechanisms in the Euro Area ...................................................... 18

V. Policies To Stabilize Business and Financial Cycles and Deliver More Convergence .......26

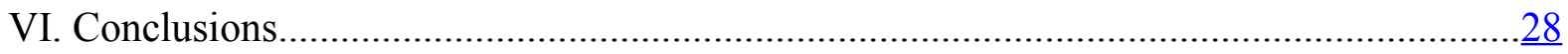

VII. Appendix: Business cycle and financial cycle analysis: Methodology and Detailed

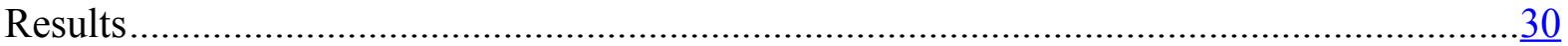

Business cycle and financial cycle measurement ….....................................

Cyclical synchronization measurement ….................................................

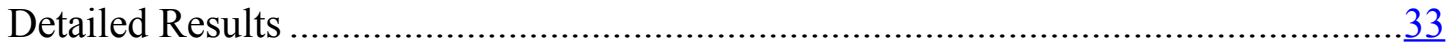




\section{INTRODUCTION}

\section{European Economic and Monetary Union (EMU) was expected to foster greater}

macroeconomic stability, prosperity, and convergence. The introduction of the single currency would stabilize exchange rates and lower interest rates across the union. Policymakers assumed that by eliminating exchange rate uncertainty and reducing crossborder transaction costs, a common currency would increase capital mobility and intraregional trade, thereby boosting growth and helping per capita income levels to converge between poorer and richer countries (Aglietta and Brand, 2013). Without recourse to devaluation, the discipline imposed by monetary union would increase incentives for policy reforms to boost productivity growth. Close coordination of fiscal policies would ensure compatibility of macroeconomic policies among member states to minimize economic fluctuations and maximize the effectiveness of the common monetary policy (European Council, 1989).

EMU succeeded in establishing a credible monetary policy framework and deepened financial integration, but many national governments failed to exercise sufficient fiscal discipline and to undertake sufficient structural reforms. In the first decade of the euro, countries benefited from a stability-oriented monetary policy framework with low interest rates, low expected inflation, and a stable, common exchange rate. However, national fiscal policies were pro-cyclical and the structural reform momentum faded, leading to macroeconomic imbalances and widening competitiveness gaps. With weak financial supervision, rapidly increasing cross-border capital flows ultimately served as a destabilizing force.

The euro area crisis has tested the stability of the euro area and exposed trends of economic divergence. The euro area is emerging from a deep crisis that has challenged the ability of its macroeconomic policy framework to deliver stability and prosperity. While countries such as Germany are now well above their pre-crisis GDP levels, in other countries such as Italy, GDP is only expected to return to its pre-crisis level in the mid-2020s. In such a weak growth environment, distributional issues become more pressing, which could cause the current widening of real income gaps to threaten the social cohesion of EMU. Moreover, the positive effects of economic union on trade, labor mobility, and productivity have been weaker than expected, while cross-border capital flows materialized, but served as a destabilizing force.

This paper examines the track record of convergence among euro area countries on a variety of dimensions. Three broad areas of convergence are explored: i) nominal convergence (interest and inflation rates); ii) real convergence (income levels and productivity); and iii) convergence of business cycles and financial cycles. We examine the economic channels expected to facilitate convergence, such as increased trade, capital flows, labor mobility, fiscal harmonization, and increased structural flexibility. The paper concludes with a discussion of policies which could improve the convergence performance. 


\section{What Kind of Convergence Does the Euro Area NeEd?}

Economic convergence on multiple dimensions was at the heart of the proposal for a common currency. The Delors Report (European Council, 1989), which outlined the path to monetary union, discussed the importance of greater convergence in economic performance and living standards, as well as in economic polices "not only in the monetary field, but also in areas of national economic management affecting aggregate demand, prices and costs of production." The promise of the 1992 Maastricht Treaty was that by giving up monetary autonomy, euro area countries would gain greater economic stability and higher growth, as the elimination of exchange rate uncertainty and lower borrowing and transactions costs would lead to more trade, labor, and capital flows.

Nominal convergence took center stage during EMU preparation. The Maastricht treaty established convergence criteria for countries to join the euro, focusing on nominal and fiscal indicators of harmonization, including: i) inflation; ii) long-term interest rates; iii) exchange rate stability; iv) the fiscal deficit; and v) the government debt-to-GDP ratio. The criteria were aimed at achieving price stability and lowering the dispersion of inflation rates while reducing excessive deficits before locking the exchange rates (Emerson et al., 1992, BiniSmaghi et al., 1993). The expectation was that the price level of tradeable goods would be equalized across countries and that inflation would generally converge, though with some scope for countries that were catching up in level of productivity and incomes to have higher inflation as non-tradable prices adjusted more slowly. The fiscal criteria aimed to reconcile a common monetary policy with decentralized fiscal policies, preventing spillovers from national policies (Andrle et al., 2015; European Commission, 2013).

The original convergence criteria have been criticized as only loosely linked to the actual economic requirements of a successful monetary union (Emerson et al., 1992; Bini Smaghi et al., 1993):

- A degree of inflation convergence is undoubtedly necessary for a well-functioning monetary policy. With a common monetary policy and decentralized fiscal policies that are bound by a common set of rules, it is difficult for policymakers to deal with large cyclical inflation differentials across countries. However, under a single currency, some inflation differentials may be needed to facilitate real exchange rate adjustment. In particular, any accumulated competitiveness gaps will need to be unwound by inflation differentials, instead of exchange rate adjustments.

- As regards nominal interest rates on government bonds, their inclusion as a criterion for accession stemmed in part from the fact that they reflect perceptions of lower country risk as well as future monetary policy. After EMU began, reduced interest rate spreads vis-à-vis Germany were seen as a dividend from monetary union. Certainly, some convergence is natural, as inflation and monetary conditions 
converge. However, with decentralized fiscal policies and different credit risk across countries, full convergence of interest rates is not desirable.

- The Maastricht fiscal criteria recognized that full fiscal harmonization was not desirable, while also acknowledging the need for fiscal discipline to assure success of the monetary union. Countries still needed the ability to respond to fiscal shocks, particularly those which affected some countries more than others. The fiscal criteria were coupled with a no-bailout clause, which was to ensure that governments did not engage in fiscally irresponsible policies, expecting the union to bail them out at a later stage. However, the Maastricht fiscal rules have been criticized as inhibiting the normal functioning of automatic stabilizers (Buiter, 2006), and the no-bailout clause lacked credibility (Allard et al., 2013).

\section{Economic theory focuses attention on cyclical convergence as a critical factor for a successful monetary union. Economies are said to display cyclical convergence is when} they are in the same phase of the business cycle at the same time and move in synch. As put forward in the Optimum Currency Area (OCA) theory, if business cycles are not synchronized, the optimal monetary policy will diverge across countries, making countries worse off with a common monetary policy than outside the monetary union. In the absence of adjustment mechanisms, idiosyncratic business cycles leave a tough burden for national fiscal policy to offset asymmetric shocks. The euro area was not generally considered an OCA at the outset. First, cyclical synchronization was limited (Eichengreen, 1991, and Bayoumi and Eichengreen, 1994). Second, the adjustment mechanisms were weak, including labor mobility (Blanchard and Katz, 1992, and Decressin and Fatas, 1995) and fiscal transfers (Sala-i-Martin and Sachs, 1991, and Godley, 1992). However, some, notably Frankel and Rose $(1997,1998)$, expected trade-creation effects would boost business cycle synchronization, and that EMU would endogenously become an OCA.

\section{More recently, financial cycles have been recognized as an important factor for stability. When EMU was created, the existence of financial cycles - and the danger that capital flows would lead to inefficient credit allocation and build financial stability risks- were not adequately recognized (Praet, 2014). Since the crisis, however, it has been increasingly acknowledged that financial cycles can amplify economic fluctuations and possibly lead to serious financial distress and economic dislocations (Claessens et al. 2011; Dell’Ariccia et al. 2012; Borio, 2014; Jordá et al. 2016; Adler et al., 2017).}

\section{Convergence of per capita income levels is not a prerequisite for a functioning} monetary union per se, but is an important objective of the economic integration process. Macroeconomic stabilization tools can operate effectively even if cross-country differences in income levels persist, as long as business cycles are synchronized. However, the Delors Report laid out income convergence - a gradual and sustained decline in differences in per capita income levels across countries - as an explicit objective of the monetary union. Indeed, shared prosperity was seen as a critical part of the "ever closer 
union" pursued since the Treaty of Rome in 1957. According to neoclassical growth theory, the removal of exchange rate risk and other barriers could produce capital flows to "catchingup" economies with lower capital-output ratios and higher marginal products of capital, thereby boosting investment and economic growth (Blanchard and Giavazzi, 2002; Praet, 2014; Tressel et al., 2014). Likewise, labor could flow from lower wage countries to higher wage ones, producing convergence in the marginal product of labor. Nevertheless, the founders of EMU also recognized that there are forces which could lead to divergence: economic activity could concentrate in more prosperous areas with a concentration of human capital and physical infrastructure (De la Dehasa and Krugman, 1992). European Union (EU) structural funds were seen as an important instrument in helping the catching-up process and addressing disadvantaged regions (Emerson et al., 1992).

Income convergence may also be important for the cohesion of the monetary union. Real economic convergence can help ensure that the gains from the monetary union are shared and thereby foster social cohesion. Furthermore, income convergence can help garner support for common insurance mechanisms to address shocks, by reducing concerns that transfers between countries could be permanent.

\section{The convergence of economic structures is not required for a successful monetary} union, but countries require sufficiently flexible labor and product markets to adjust to shocks. With a single currency, countries need to be flexible to allow relative prices to adjust to shocks. If not, a heavier adjustment burden falls on the quantities (employment and output). This does not imply identical product and labor markets, but ensuring that factors can move to their most efficient uses and be reallocated quickly. Under the initial conceptualization of the Delors Report, "measures designed to strengthen the mobility of factors of production and the flexibility of prices would help to deal with...imbalances" under the monetary union. More recently, differences in labor and product markets, social security and welfare policies have been seen as playing an important role in explaining divergence in economic performance (auf dem Brinke et al., 2015).

\section{Have Euro Area Countries Converged?}

\section{A. Nominal Convergence}

Inflation rates converged substantially before euro adoption, but did not align further thereafter. Amid global disinflation trends and in line with the convergence criteria for price stability that countries had to meet to join the euro area, inflation rates in EA-12 countries converged toward the rates in low-inflation countries (text chart, and European Monetary Institute, 1998). ${ }^{2}$ Average inflation dropped from 3 percent in 1995 to 1.3 percent in 1998, and the standard deviation of inflation rates across countries was reduced from 2.4 percent to

${ }^{2}$ EA-12 denotes the twelve founding euro area countries: Austria, Belgium, Finland, France, Germany, Greece, Ireland, Italy, Luxembourg, the Netherlands, Portugal and Spain. 
around 1 percent during the same period (and from 5 percent in 1990, at the outset of Stage 1 of EMU). Since then, however, inflation rates have not converged much further. Differences in cyclical positions explain part of this phenomenon, with some countries experiencing rapid increases in economic activity and significantly higher-than-average inflation prior to 2008 . However, in the ensuing years of contraction in these countries, inflation remained close to the euro area average, pointing to structurally higher inflation in these economies. Another possible explanation for the lack of additional convergence in inflation rates could be that countries with initially lower price levels experienced higher inflation, as tradable goods prices equalized across countries in the monetary union. However, this hypothesis is not supported by data, which shows that the variation of price levels across EA-12 countries remained broadly unchanged during the first 15 years of the euro (text chart). In contrast, countries that joined the euro area in 2007 or later, as well as non-euro area EU countries, did experience continued price level convergence.
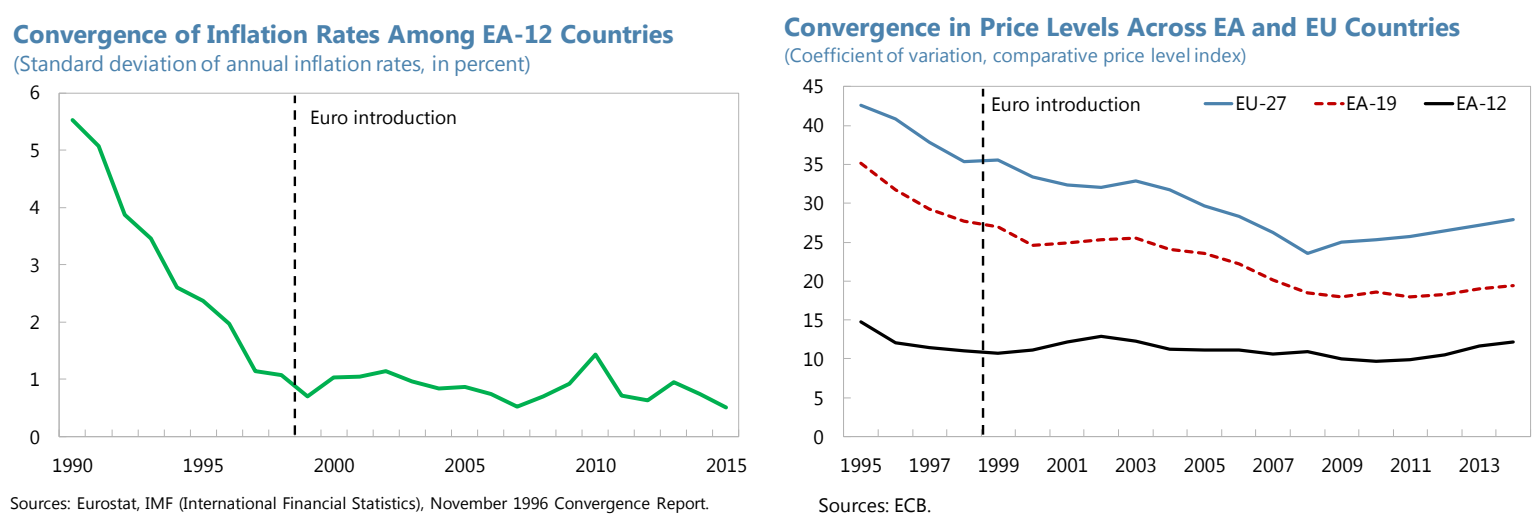

While the variation in inflation rates across euro area countries is relatively small, the persistent inflation differentials contributed to competitiveness gaps. Looking at average inflation rates over 1999-2007, the same countries (Ireland, Greece, Spain, and Portugal) were consistently in the upper end of the inflation distribution (text chart). This persistence of higher inflation led to a progressive deterioration in these countries' competitiveness over time, as reflected in widening gaps in real effective exchange rates.
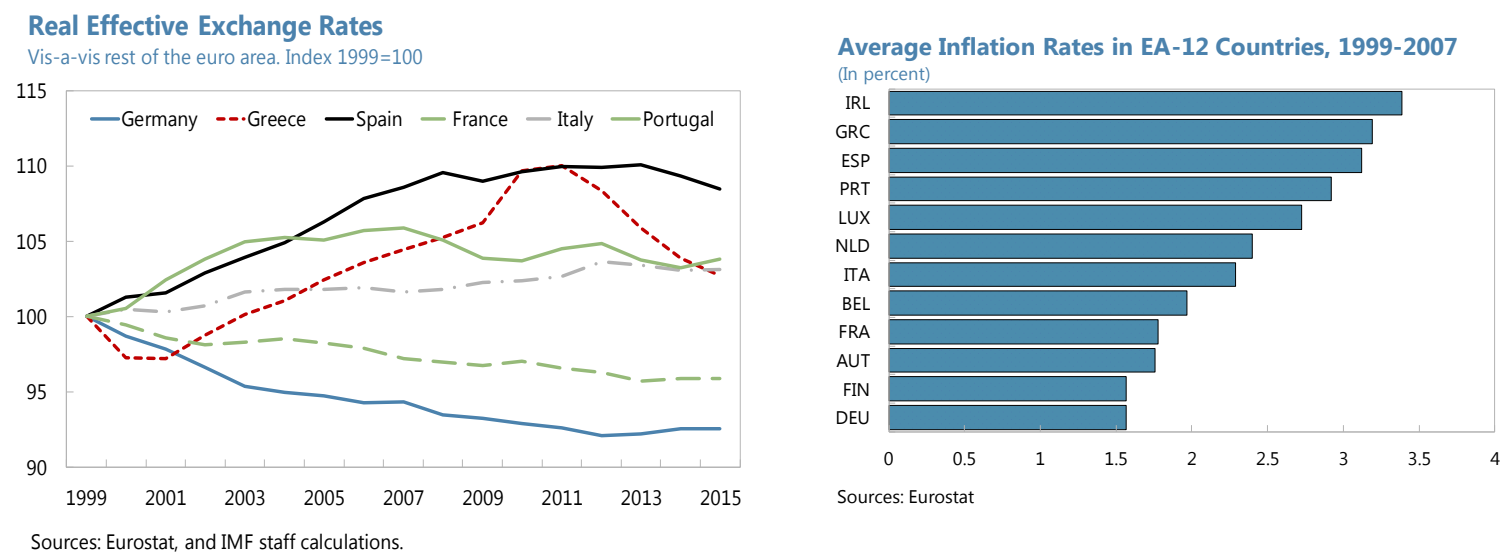


\section{Nominal interest rates also converged, but the convergence was undone during the}

crisis. In line with the convergence criteria, long-term interest rates converged toward the levels in low-inflation countries prior to euro adoption and remained compressed during the next decade (text charts). Countries with the largest initial government bond spreads over Germany saw the largest subsequent declines. However, the convergence in interest rates also implicitly meant that markets stopped differentiating credit risk across governments, based on a belief that euro area sovereigns would never default. This effectively undermined governments' incentives for economic reform to improve productivity and competitiveness (Treichel, 2012). With the financial crisis, markets repriced debt as the differences in credit risk became more apparent. The convergence dynamic thus went into reverse, as the countries with the largest spreads at the time of the Maastricht Treaty experienced the most dramatic increases. ${ }^{3}$
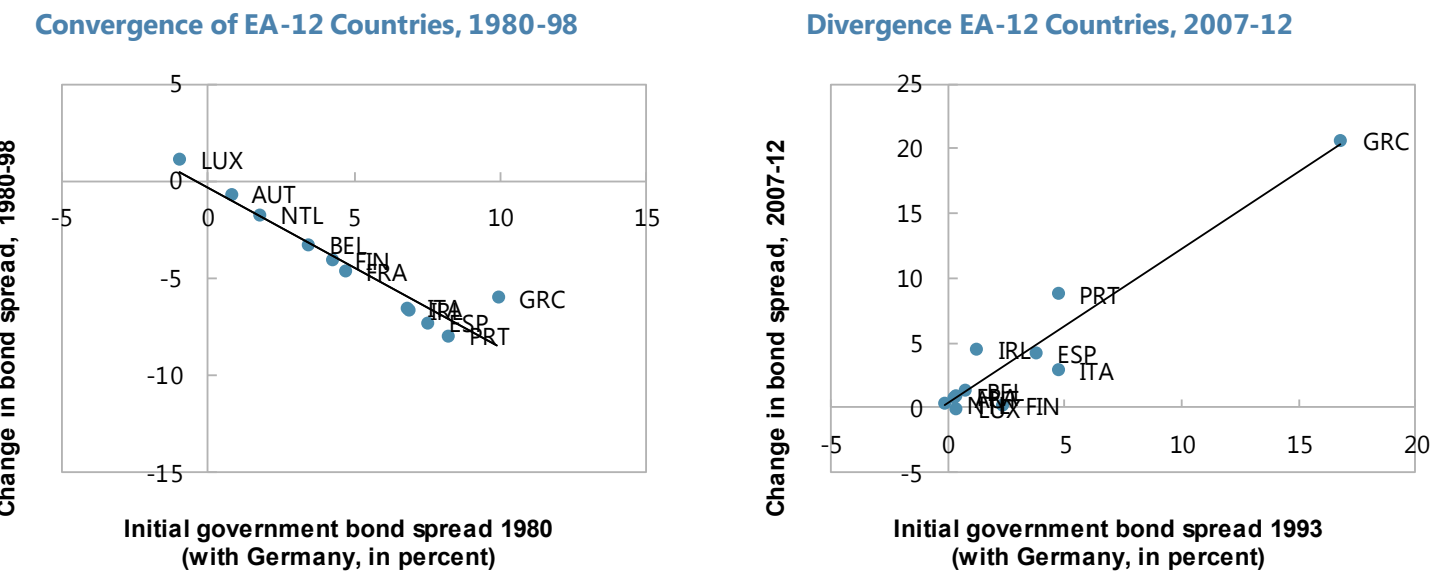

As a result, real interest rates fell sharply in some countries and overshot convergence, dropping below Germany's real rate. With nominal interest rates converging more completely than inflation rates, higher-inflation countries had lower real rates, which in turn fueled credit booms and domestic demand, re-enforcing

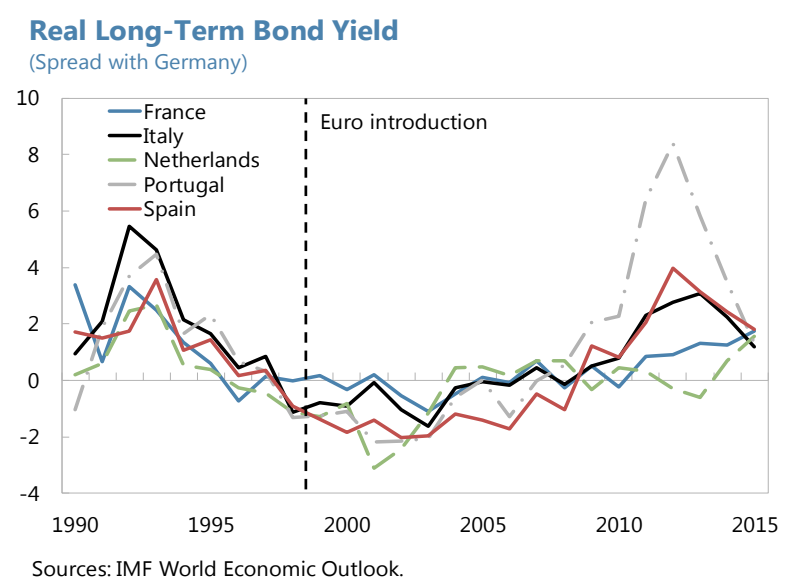

${ }^{3}$ Buti and Turrini (2015) and Barkbu et al. (2016).

(continued...) 
inflationary pressure. ${ }^{4}$ In fact, countries that had previously had real interest rates above Germany's experienced lower real interest rates than Germany from about 1999 (text chart). This trend was later reversed, when real rates rose sharply outside Germany as nominal interest rates increased and inflation fell in the aftermath of the crisis.

\section{To summarize, the cumulative effect of small, but persistent inflation differentials and converging nominal interest rates after euro introduction hampered real convergence.} First, since in most cases the inflation differentials did not reflect productivity increases, common nominal interest rates implied relatively low real interest rates in these economies, which exacerbated the cycles and added further to inflation differentials prior to the crisis. Second, in the absence of exchange rate flexibility at the country level, the persistent inflation differentials meant that high-inflation countries lost competitiveness, thereby dampening potential growth. The high-inflation countries had initially lower GDP per capita, implying that the inflation differentials worked against convergence.

\section{B. Real Convergence: Income and Productivity}

\section{There was steady income convergence across euro area countries in the decades leading up to the Maastricht Treaty. ${ }^{5} \mathrm{We}$ consider at two complementary indicators of income convergence (following Sala-i- Martin, 1996): (i) $\beta$-convergence, which looks at whether countries with lower GDP per capita grow faster than those with higher GDP per capita, also referred to as catching-up; and (ii) $\sigma$-convergence, which}

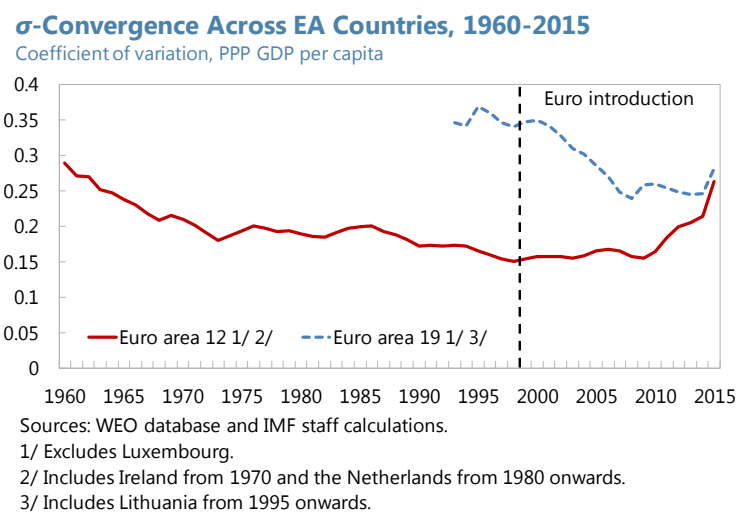
looks at whether the dispersion of countries' GDP per capita decreases over time. Both concepts are needed to gauge the quality of convergence, as faster growth of countries with initially lower income levels is not a sufficient condition to ensure a decline in the dispersion of income levels across countries. ${ }^{6}$ During 1960-1992, EA-12 countries with lower GDP per capita grew faster than richer ones, indicating strong $\beta$-convergence (Table 1). The dispersion of GDP per capita across countries also fell, implying $\sigma$-convergence (text chart).

\footnotetext{
${ }^{4}$ See Appendix Figure 4.

${ }^{5}$ This finding is consistent with other research. See Kaitila (2014), auf dem Brinke et al. (2015), ECB (2015), and Barkbu et al. (2016). See IMF (2017a) for a more detailed discussion of the results presented in this section.

${ }^{6}$ Per capita GDP at purchasing power parity (PPP) is used to control for cross-country differences in price levels. For assessing $\beta$-convergence, there is a trade-off between using real GDP data, which is comparable over time, and PPP GDP data, which is comparable across countries. The subsequent analysis uses the latter, to allow the comparison of living standards across countries, but includes robustness checks with real GDP data.
} 
Table 1: $\beta$-convergence among euro area countries ${ }^{1}$

\begin{tabular}{|c|c|c|}
\hline $\begin{array}{l}\text { EA-12 } \\
\text { (excl. Luxembourg) }\end{array}$ & $\beta$ & $\mathbf{R}^{2}$ \\
\hline $1960-2015^{3}$ & $1.93 * * *$ & 0.77 \\
\hline $1960-1992^{3}$ & $3.86^{* * *}$ & 0.91 \\
\hline 1990-1998 & 7.83 & 0.23 \\
\hline 1999-2015 & -6.28 & 0.24 \\
\hline 1993-2015 & 5.64 & 0.10 \\
\hline $\begin{array}{l}\text { EA-19 } \\
\text { (excl. Luxembourg) }^{2}\end{array}$ & $\beta$ & $\mathbf{R}^{2}$ \\
\hline $1990-1998^{4}$ & $9.40 * *$ & 0.38 \\
\hline 1999-2015 & $8.08 * * *$ & 0.66 \\
\hline $1993-2015^{5}$ & $6.59 * * *$ & 0.64 \\
\hline $\begin{array}{l}\text { memo: EU-28 } \\
\text { (excl. Luxembourg) }^{2}\end{array}$ & $\beta$ & $\mathbf{R}^{2}$ \\
\hline $1993-2015^{6}$ & $5.25 * * *$ & 0.63 \\
\hline
\end{tabular}

Note: *** significant at 99 percent level; ** significant at 95 percent level; * significant at 90 percent level.

$1 /$ Linear cross-country regressions of average annual PPP GDP per capita growth $(\gamma)$ between time $t+1$ through $\mathrm{T}$ on the logarithm of PPP GDP per capita $(\mathrm{y})$ at time t. Positive values indicate convergence:

$\gamma_{i, t+1, t+T}=\alpha-\beta \log \left(y_{i, t}\right)+\varepsilon_{i, t}$.

2/ Luxembourg excluded because it is an extreme outlier with high PPP GDP per capita.

3/ No data available for Ireland and the Netherlands.

4/ No data available for Estonia, Latvia, Lithuania, Slovak Republic and Slovenia.

5/ No data available for Lithuania.

6/ No data available for Czech Republic and Lithuania.

However, contrary to expectations, income convergence among EA-12 countries slowed after Maastricht and subsequently came to a halt. ${ }^{7}$ While 23 years is a short time span for convergence analysis, regressions point to a lack of $\beta$-convergence of GDP per capita from 1993 to 2015 (Table 1). The time-series plots of cross-country income dispersion $(\sigma-$ convergence) show slow convergence in the 1990s, lack of convergence in the first decade of the euro, and divergence since the crisis, reversing the initial narrowing in income dispersion.

\section{At the same time, countries that joined the euro area in 2007 or later experienced} continued convergence in the run-up to their accession. ${ }^{8}$ Income differences between 'old' and 'new' euro area members were large in the 1990s, but narrowed substantially prior to EU

\footnotetext{
${ }^{7}$ Kaitila (2014), auf dem Brinke et al. (2015), ECB (2015), and Barkbu et al. (2016) find similar results.

${ }^{8}$ See also Benczes and Szent-Ivanyi (2015), ECB (2015), and Forgo and Jevčák (2015).
} 
and euro area accession of the latter group (text charts). However, convergence for these countries has also slowed since the financial crisis, while for the EA-19 as a whole it has stalled. Despite the weaker convergence performance in recent years, over the entire period 1993-2015 convergence among the 19 countries now in the euro area has been significantly higher than between EU-28 countries as a whole (Table 1). ${ }^{9}$
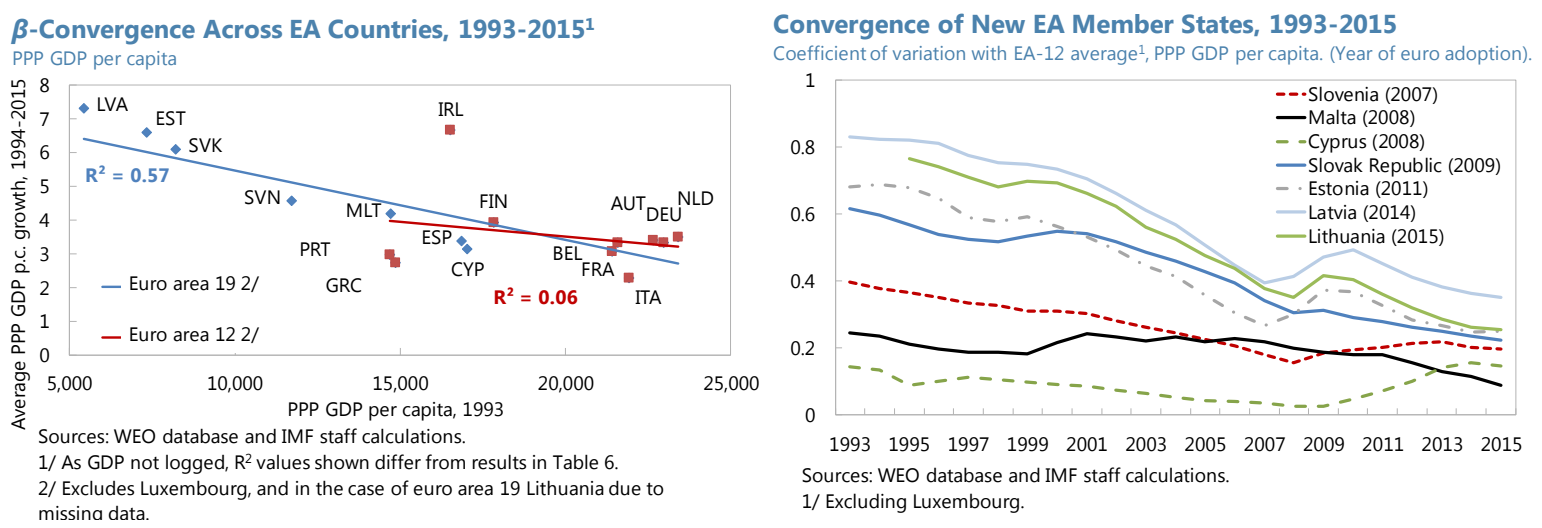

Productivity among the EA-12 diverged under the single currency. While productivity growth has slowed in recent decades throughout Europe, the decline was more pronounced in some countries than in others. Contrary to expectations, there was no productivity catch-up following the introduction of the euro (Diaz del Hoyo et al., 2017; IMF, 2017). A decomposition of annual GDP per capita growth across countries with high and low initial productivity levels shows that countries with low initial productivity have had consistently lower TFP growth and experienced a sharper slowdown over recent years (text chart). The less efficient use of factors of production more than offset the growth contribution of greater capital investment in these countries, forestalling real convergence. A larger fall in investment and employment since 2008 further added to the post-crisis divergence

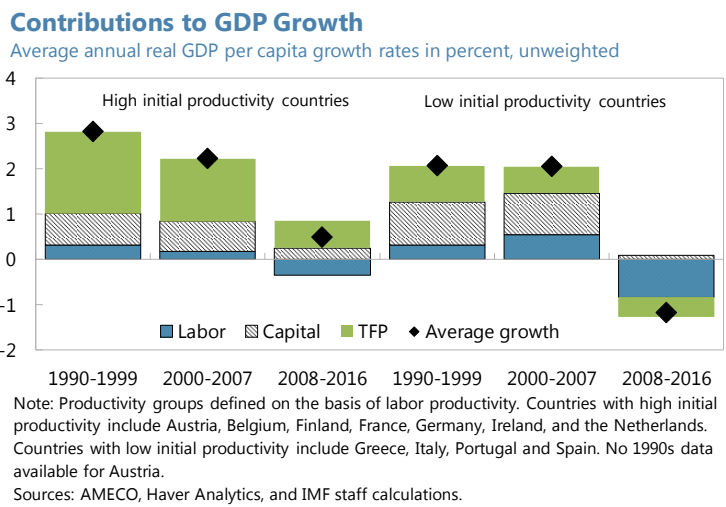
in economic growth.

\footnotetext{
${ }^{9}$ Of course, this stronger convergence may reflect the convergence demands of the accession process before joining rather than convergence under the monetary union. It may also be the result of selection bias-countries already more likely to convergence were the ones who chose to join the euro.
} 


\section{Business Cycle Synchronization}

Recent research finds mixed evidence on cyclical convergence in the euro area. While De Grauwe and Ji (2016) find that the average bilateral business cycle correlation is higher within the euro area than outside, they do not consider if the degree of synchronization has evolved over time. Enderlein, Letta et al. (2016) note a lack of improvement in business cycle synchronization since the start of EMU. Bayoumi and Eichengreen (2017) find the euro area falling short of an OCA in its response to aggregate demand and supply shocks, with little evidence of the "endogeneity of the optimal currency area criteria."

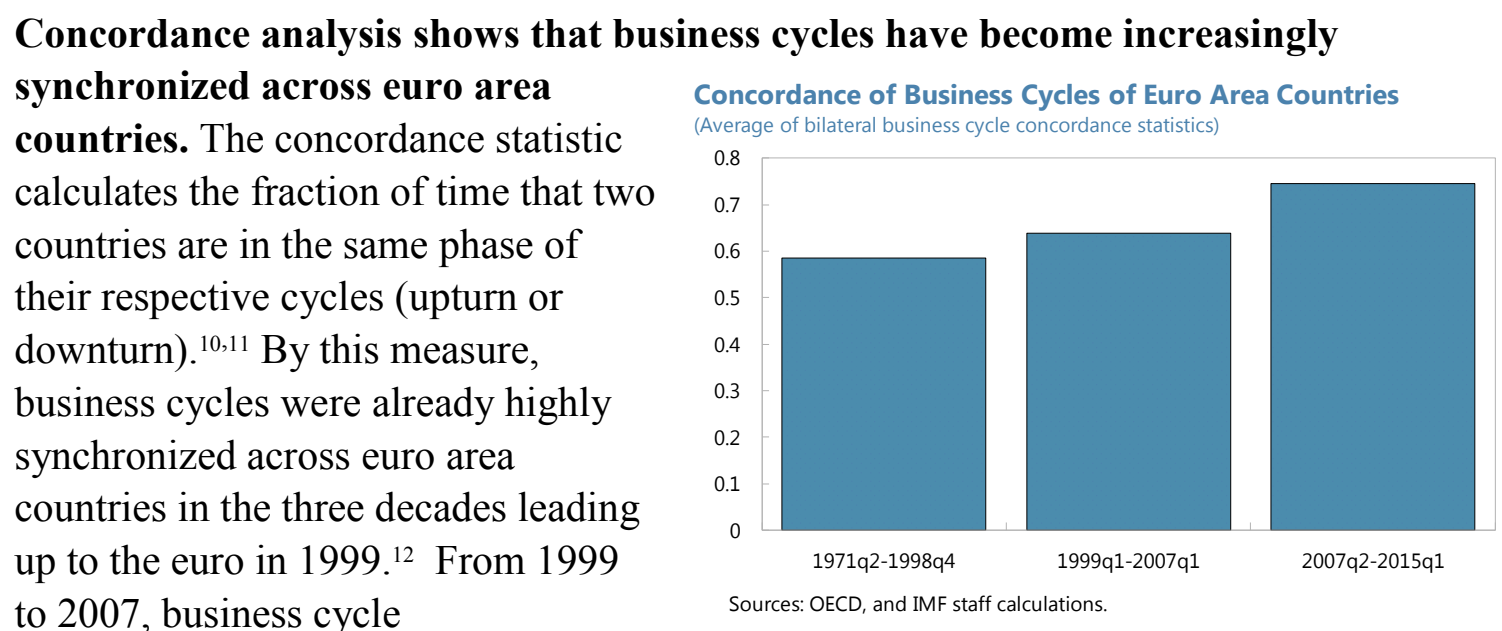

synchronization increased further, followed by an additional sharp increase in the post-2008 period (text chart and Appendix Tables 1-3). ${ }^{13}$ The increase in concordance was broad-based. Germany in particular has experienced increasing synchronization over time, and is the country with the highest degree of synchronization post crisis.

\footnotetext{
${ }^{10}$ Specifically, countries are perfectly pro-cyclical (countercyclical) if the concordance statistic is equal to one (zero). The literature suggests that a concordance statistic above 0.6 constitutes a high degree of synchronization. To extract the short-term cyclical component, we use the band-pass filter in Christiano and Fitzgerald (2003) with duration between 5 and 32 quarters to isolate the short-term cyclical component of real, seasonally-adjusted GDP normalized to 1985Q1. We look at the EA-12, minus Luxembourg. See the details in the Appendix.

${ }^{11}$ The main reason for focusing on concordance instead of correlation is that the latter combines the amplitude and duration dimensions of covariance into a single measure, making it hard to interpret whether a high number reflects significant co-movement over time or a single large event that is common to two time series

(McDermott and Scott, 2000).

${ }^{12}$ Ireland is an exception, with a relatively low degree of synchronization

${ }^{13}$ See the Appendix for explanations on the choice of periods.
} 
However, after some initial narrowing, the amplitude of business cycles has diverged. A complementary measure of the degree of synchronization examines the amplitude of the cycles, measured by the (negative of) the average absolute differential of smoothed quarterly real GDP growth rates for all euro area country pairs. Full synchronization is achieved when the differential is zero, with a lower number reflecting a lower degree of synchronization. On this basis, there were larger differentials in growth rates after the crisis hit, i.e. less synchronization in the amplitude of the cycles (text chart). Hence, while business cycles have become more synchronized during EMU, the size of these fluctuations has diverged.

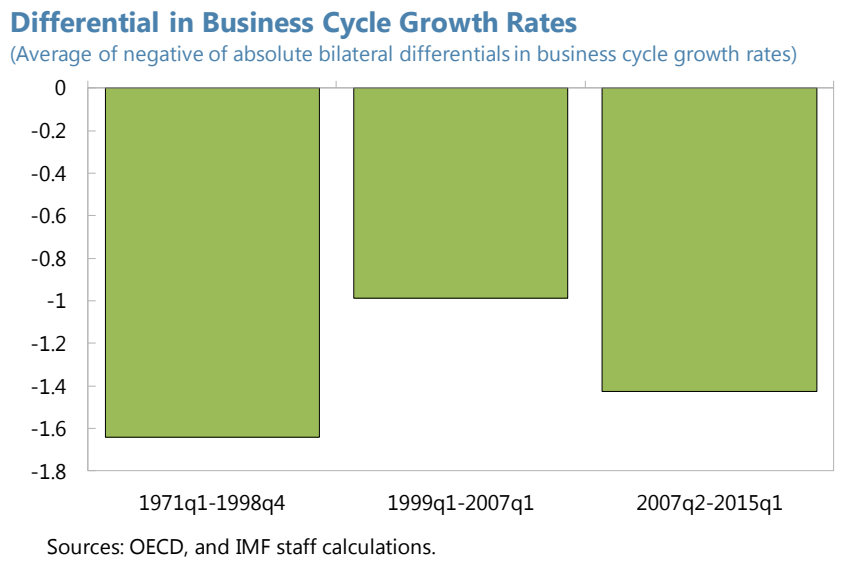

The implications for economic policymaking are mixed. While the high degree of cyclical synchronization ensures that the common monetary policy points in the right direction for most EMU member states, the divergence in amplitude means that the optimal degree of tightening or loosening of macroeconomic policies would differ for different countries.

\section{Financial Cycle Synchronization and Capital Flows}

The degree of synchronization of financial cycles in the euro area has received less research attention, despite rapid financial integration after the launch of the euro. The expectation when the Maastricht Treaty was negotiated was that financial integration would boost growth through the elimination of transaction and exchange rate costs and more efficient capital allocation (Delors Report, 1989). The sharp increases in cross-border capital flows could also enhance the potential for more synchronized financial cycles. On the other hand, freer capital flows may also prove destabilizing for business cycle and real convergence if capital feeds speculative bubbles in boom times and capital flight exacerbates downturns in crisis times.

Boom-bust financial cycles are linked to lower long-term growth, and hence can impair real income convergence. Theory suggests that financial cycle booms produce financial imbalances in borrowers' and lenders' balance sheets, masked by higher asset prices and a temporary boost to output. Subsequently, a turn in the financial cycle results in a debt overhang and a higher probability of financial crisis, exacerbating the ensuing business cycle downturn and generating hysteresis, as deleveraging by firms and households coupled with credit contraction puts persistent downward pressure on incomes and private investment, ultimately lowering trend growth (Aglietta and Valla, 2017). Empirically, Jordá et al. (2016a, $2016 \mathrm{~b}$ ) find that the aftermaths of leveraged booms are associated with slower growth in GDP, investment and credit, and larger tail events. Furthermore, financial boom-busts are 
associated with lower TFP growth (Cecchetti and Kharroubi, 2015), reflecting resource misallocation both across sectors (Borio et al., 2015) and within firms (Adler et al., 2017), as a result of tight credit conditions and weak corporate balance sheets.

\section{In contrast with business cycles, the degree of financial cycle synchronicity fell in the initial phase of the euro, but then rose in the wake of the crisis. A euro area financial} cycle upswing started around the time of the euro introduction and lasted until the financial crisis. The downturn started with the crisis in 2009 and lasted through the end of the estimation period. The average concordance of national financial cycles fell in the first decade of the euro, but increased during the crisis period starting in 2007 (text chart). ${ }^{14}$ Since the crisis, nine of the eleven countries showed higher concordance than in the pre-euro period. While the overall degree of financial cycle synchronization was similar to that of business cycles, bilateral financial cycle concordance numbers varied much more widely than those of business cycles, indicating greater dispersion among countries. ${ }^{15}$

Germany's financial cycle has become increasingly disconnected from the others. Unlike its euro area peers, Germany's bilateral financial concordance fell both in the pre- and postcrisis periods, to the lowest level observed among all EA-12 countries (Table 2). ${ }^{16}$. This is in part because Germany has a remarkably flat financial cycle, with an almost 40 percent lower standard deviation than the euro area average. This disconnect reflects Germany's distinctive credit and house price dynamics, which differ from those of most EA-12 countries. Credit to the private non-financial sector remained flat between 2004 and 2011, preventing a

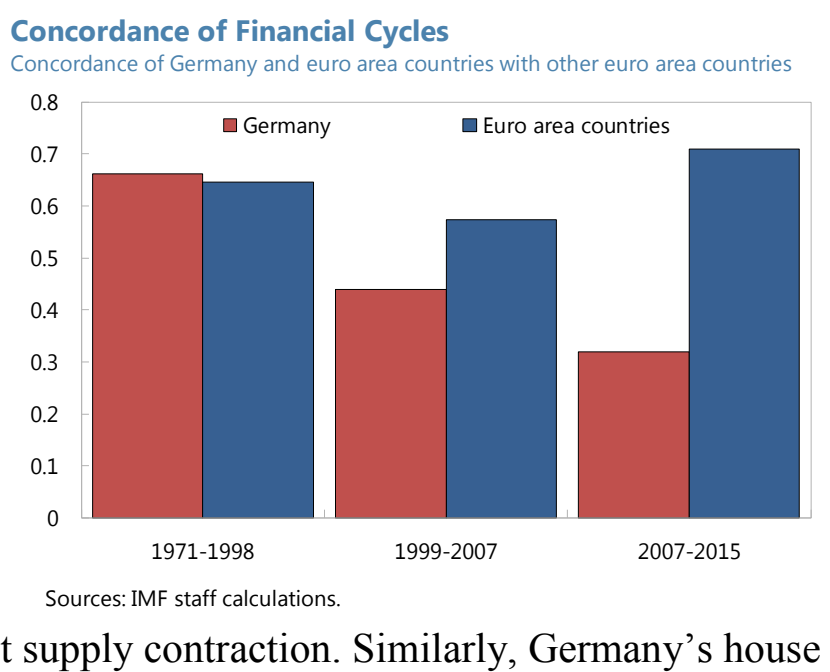

subsequent private debt overhang and credit supply contraction. Similarly, Germany's house

\footnotetext{
14 The financial cycle is estimated as in Drehmann et al. (2012), by a multivariate frequency-based filter, in year-on-year percentage change, applied to the credit-to-GDP ratio, credit to the non-financial private sector, and residential property prices (all normalized to 1985Q1) for EA-12 countries except Luxembourg. Credit and residential property prices are in real terms (deflated by CPI) and in four-quarter differences in log levels. The financial cycle is defined by the average of the medium-term cyclical component of the three time-series. See the Appendix for details.

${ }^{15}$ See details in Appendix Figure 1.

${ }^{16}$ Using turning point and concordance analysis, Hiebert et al. (2017) also find that Germany's financial cycle is out of synch with those of other European countries.
} 
prices remained stable until 2009 and grew relatively slowly thereafter. The relatively low home ownership rate in Germany may also have played a role. ${ }^{17}$

Table 2: Mean Concordance of Financial Cycles with Other Countries

\begin{tabular}{|c|c|c|c|}
\hline & $\mathbf{1 9 7 1 - 1 9 9 8}$ & $\mathbf{1 9 9 9 - 2 0 0 7}$ & $\mathbf{2 0 0 7 - 2 0 1 5}$ \\
\hline Austria & 0.71 & 0.65 & 0.80 \\
\hline Belgium & 0.67 & 0.67 & 0.75 \\
\hline Finland & 0.65 & 0.69 & 0.80 \\
\hline France & 0.70 & 0.38 & 0.78 \\
\hline Germany & 0.66 & 0.44 & 0.32 \\
\hline Greece & 0.58 & 0.68 & 0.69 \\
\hline Ireland & 0.66 & 0.61 & 0.80 \\
\hline Italy & 0.65 & 0.55 & 0.78 \\
\hline Netherlands & 0.63 & 0.59 & 0.81 \\
\hline Portugal & 0.53 & 0.60 & 0.52 \\
\hline Spain & 0.66 & 0.45 & 0.75 \\
\hline Average & 0.65 & 0.57 & 0.71 \\
\hline GDP- & & & \\
\hline weighted & 0.66 & 0.49 & 0.64 \\
\hline average & & & \\
\hline
\end{tabular}

Our analysis shows a large and growing variation in amplitudes across national

financial cycles. In particular, financial cycles were strongly amplified in Spain, Ireland, and Greece, with standard deviations close to five times the euro area average. These countries experienced financial cycles of increasing duration and magnitude after euro introduction, in sharp contrast to core euro area countries, as cross-border bank flows from core country banks to the private (Spain, Ireland) and public (Greece) sectors boomed. ${ }^{18}$

\footnotetext{
${ }^{17}$ See Appendix Figure 3. Huber (2016) finds evidence of a strong positive correlation between homeownership rates and house price fluctuations in OECD countries.

${ }^{18}$ See details in Appendix Table 8 and Appendix Figures 1 and 3.
} 

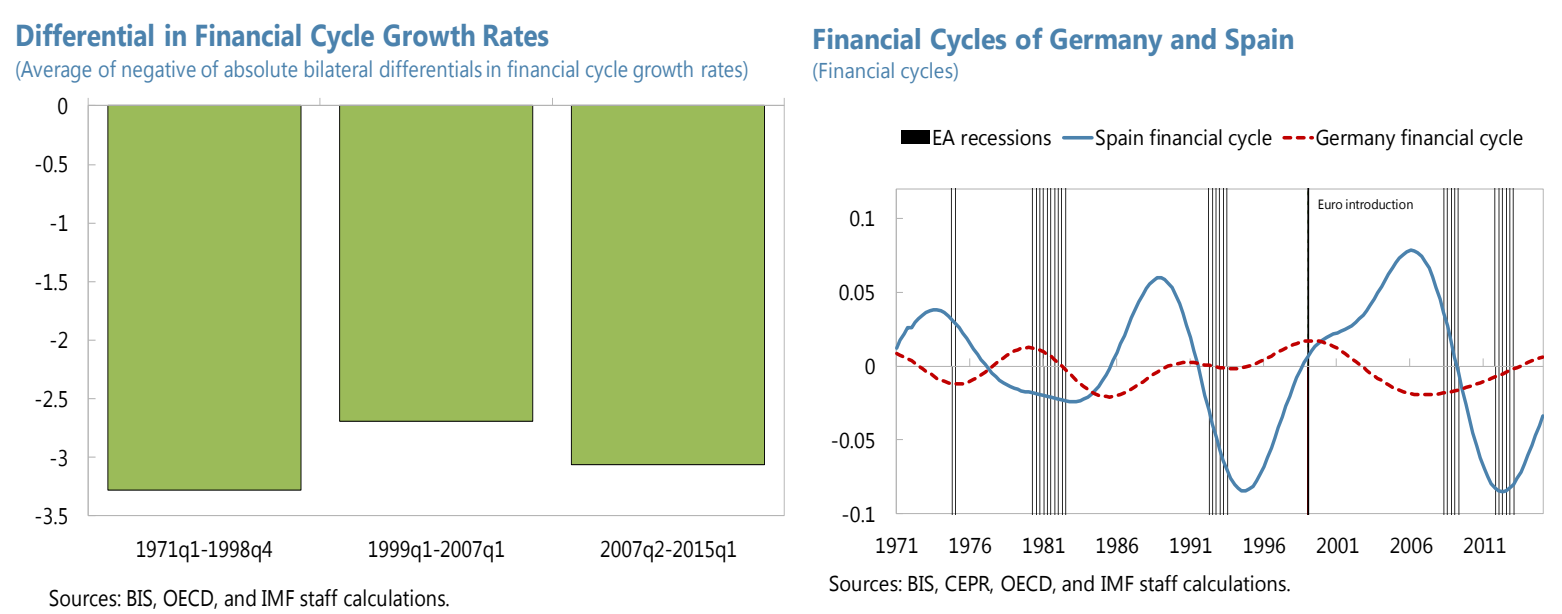

\section{AdJustment Mechanisms in the Euro Area}

Cross-country flows in labor, capital, goods, and services markets were expected to help income convergence and countries' capacity to adjust to shocks within the single currency. In the face of common cyclical shocks, it was envisaged that fiscal policies would work with the common monetary policy to dampen the business cycle. In the face of asymmetric shocks, improved structural flexibility would help adjustment via flexibility in wages and prices, while capital and labor would flow to greater business opportunities, attenuating the business cycle differences across countries. For the longer-term challenge of real income convergence, it was expected that investment would flow from higher income to lower income countries, while labor would flow in the opposite direction. Internal trade possibilities would encourage greater production in lower income countries.

\section{However, the envisaged adjustment mechanisms under monetary union have been} insufficient to support convergence, and have in some cases contributed to divergence. Labor mobility remained modest and trade integration was less than expected. Countries did not advance structural reforms as expected, and fiscal policy in practice was often procyclical rather than countercyclical. Capital flows did boom spectacularly in the early years of monetary union, but they proved destabilizing rather than shock absorbing, as demonstrated by the sharp reversal of capital flows during the crisis. Moreover, these capital flows did not generate convergence of productivity to produce sustained real income convergence. Recent ECB research (Constâncio, 2016) suggests that some 80 percent of income risk remains unsmoothed through fiscal, price, credit, and capital flow channels, and that the degree of risk-sharing has actually fallen in recent years. We briefly examine the effects of trade, labor market, capital flows, structural reforms, and fiscal policies for cushioning idiosyncratic shocks and find little smoothing. 
Intra-euro area trade is substantial, but has not increased as much as predicted. Contrary to expectations (Rose, 2000), there is little evidence that EMU has stimulated trade. Intra-euro area trade increased less than trade with non-euro area countries. While intra-euro area goods trade continued to increase as a share of GDP, from 20 percent of GDP in 1993 to 30 percent of GDP in 2008, extra-euro area trade increased even more (text charts). As a share of total trade, intra-euro area trade rose from around 40 percent in 1960 to around 55 percent at the time of the Maastricht Treaty in 1992, but fell back to 40 percent in 2013. ${ }^{19}$ Glick and Rose (2015) find that the effect of EMU on trade has likely been small.
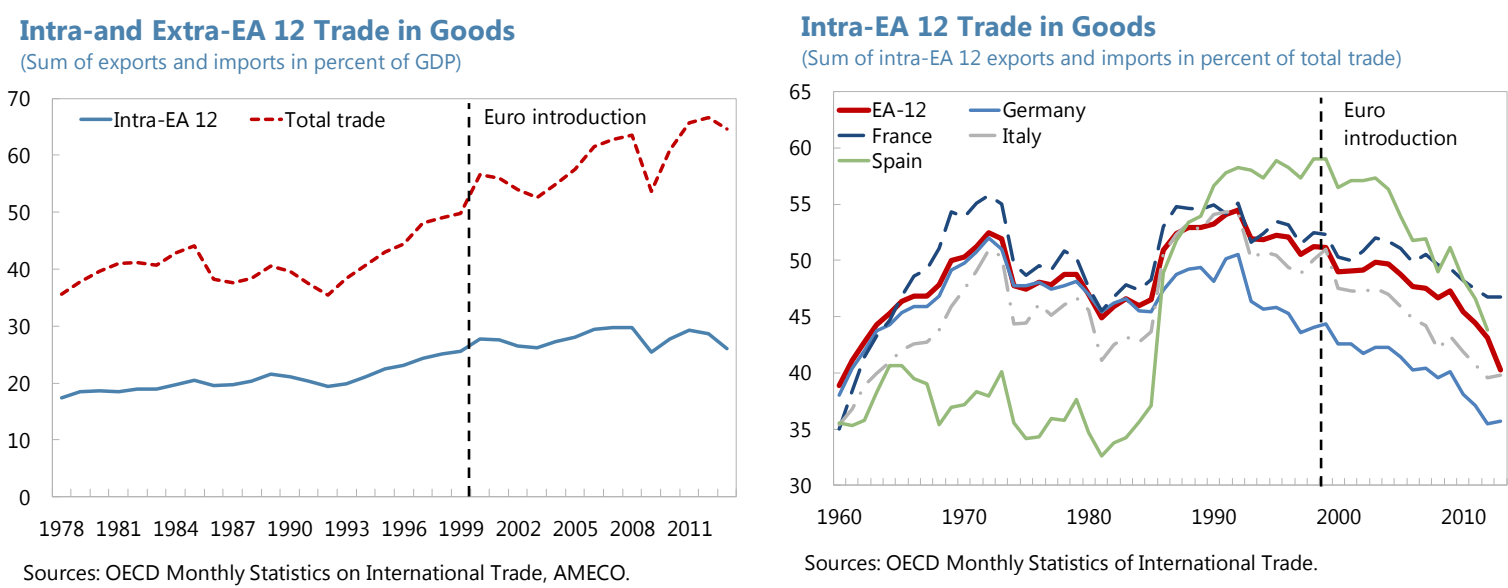

The adjustment impact from intra-EU labor mobility has also been modest.$^{20}$ It was acknowledged at the outset of EMU that labor mobility was unlikely to increase substantially, due to language, cultural and administrative barriers (Emerson et al., 1992). While the share of EU working-age citizens living in another EU country doubled over the last decade, at a little above 3 percent it is still only a fraction of the labor mobility observed in the U.S. (text charts). For the EU-15, which include the founding members of the euro, mobility is even lower, at 2 percent. In fact, most of the recent rise in intra-EU mobility is due to East-West flows following EU enlargement, as can be seen by the increase in EU-28 flows. According to the EC and the OECD, labor mobility may absorb up to a quarter of labor demand shocks in the EU-15 countries and the euro area, respectively (Arpaia et al., 2014; Jauer et al., 2014). However, this estimate is likely to constitute an upper bound, as the OECD's analysis counts all migration, including non-labor-market-related migration.

\footnotetext{
${ }^{19}$ The same patterns can be found when looking at value-added data. Similarly, the share of intra-euro trade in services declined.

${ }^{20}$ Labor mobility data exist for EU-28 and EU-15, but not for euro area countries. EU-15 denotes the EA-12 countries plus Denmark, Sweden and the United Kingdom.
} 
Share of Population Outside Home Border (In percent) $1 /$

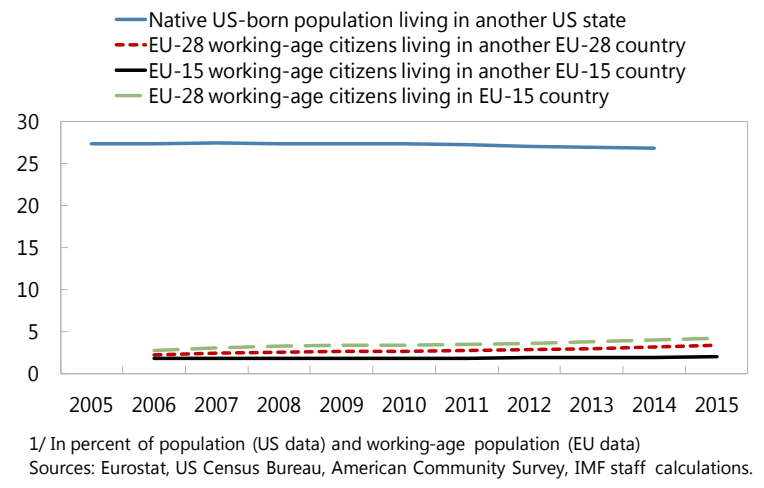

Employment from EU-15 Countries by Host Country In percent of domestic employment

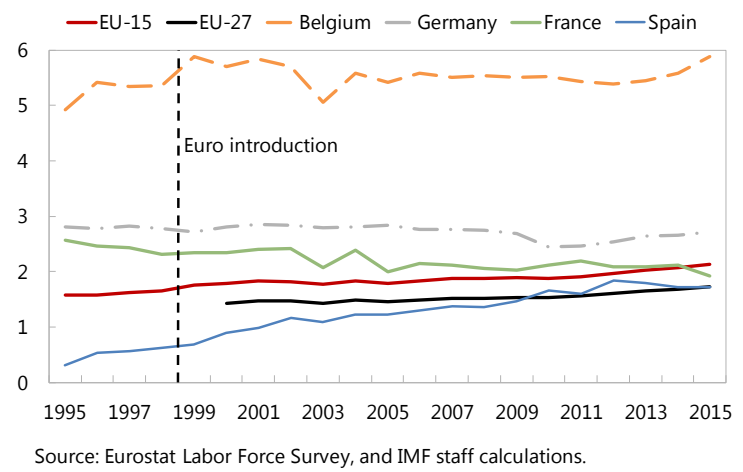

Capital flows, meanwhile, increased substantially, but financed investments in lowproductivity sectors and drove unsustainable booms. The elimination of currency risk and the lowering of interest rates boosted intra-euro area capital flows, with cross-border claims in euros of euro area banks rising from below $€ 1$ trillion in 1998 to close to $€ 10$ trillion at the peak in 2008. In particular, banks in core countries increased substantially their claims on banks in periphery countries (text chart). As a result, periphery countries experienced strong growth in domestic - especially bank - credit to the private non-financial sector. ${ }^{21}$ Banks concentrated their new lending in sectors with low productivity, especially housing, construction and other real estate activities, fueling housing price bubbles in Spain and Ireland, increasing risks to financial stability. When the euro area crisis hit in 2010, capital flows were reversed, forcing rapid adjustment.

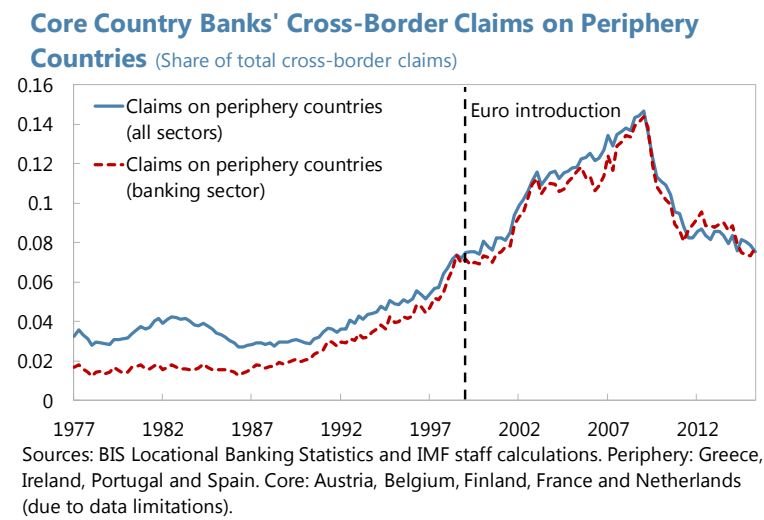

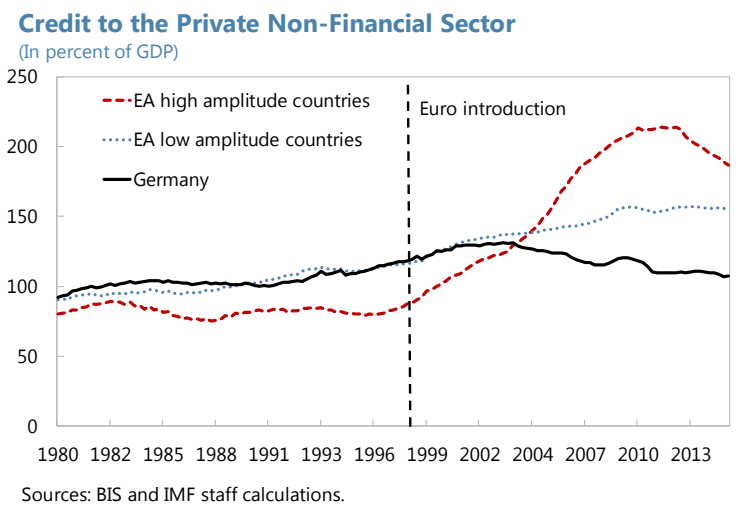

${ }^{21}$ There is a strong cross-country correlation, over the 1999-2007 period, between the increase in cross-border liabilities of high-financial cycle amplitude countries' banks and the average growth differential between these countries' financial cycles and the financial cycles of low-amplitude countries. 
At the same time, foreign direct investment (FDI) flowed disproportionately to Central European countries, rather than other euro area countries. FDI is typically more stable capital, as it represents equity rather than debt, is long-term, and is associated with increased domestic capital formation rather than increased consumption. Starting in the 1990s, the rise of the German-Central European Supply Chain led to a rapid expansion in bilateral trade linkages between Germany and the Czech Republic, Hungary, Poland, and the Slovak Republic. The supply chain production was supported by large FDI flows from Germany, in contrast to FDI flows to Southern EMU countries (text chart). Following the introduction of the euro, manufacturing activity stabilized in Northern euro area countries (led by Germany), and declined in Southern countries (Wolff and Vihiriälä, 2013).

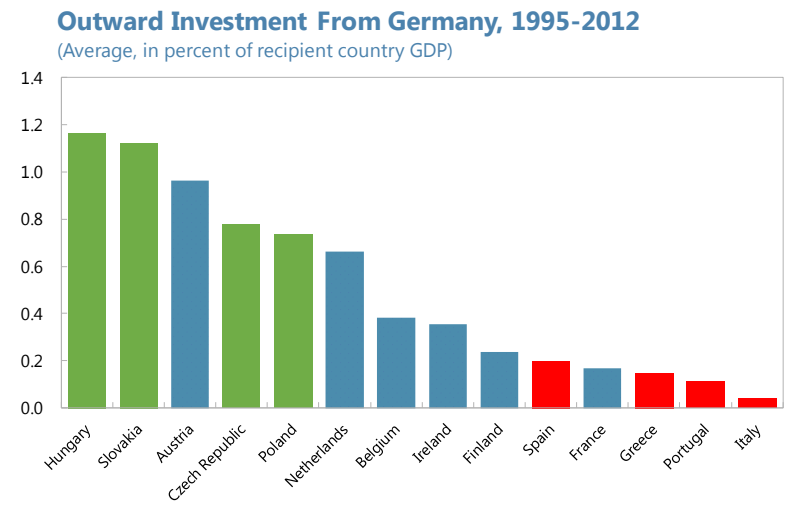

\section{EMU membership did not generate structural reforms beyond what was observed in} other advanced economies. ${ }^{22}$ The founders of EMU expected that national policymakers would have strong incentives for domestic structural reforms to boost flexibility and productivity, given the loss of the exchange rate tool to close competitiveness gaps. Euro area countries did reduce barriers to competitiveness in their product markets between 1988 and 2013, the latest available data point (text chart). ${ }^{23}$ However, the degree of dispersion of the level of competition barriers across euro area countries has not declined over time (Appendix Figure 5). Labor tax policies diverged in the first ten years of EMU, which set different incentives for employment across countries and influenced their potential growth. The dispersion of labor tax wedges increased significantly with the introduction of the euro in 1999 (text charts). Tax wedges across EMU countries converged again from 2009 onwards, in 2015 reaching a level of convergence last observed in the early 1990s.

\footnotetext{
${ }^{22}$ The overall level of competition barriers decreased by about one third in this period, though progress differed across subcategories. Nonetheless, the evolution in product market competition in the euro area was fairly similar to that in the OECD.

${ }^{23}$ EA-12 countries, except for overall product market regulation (which does not have data for Luxembourg in 1998).
} 


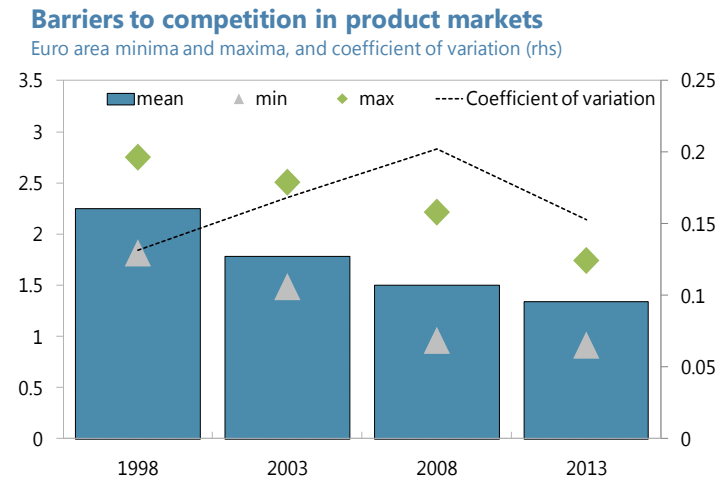

Sources: OECD Indicators of Product Market Regulation, and IMF staff calculations.

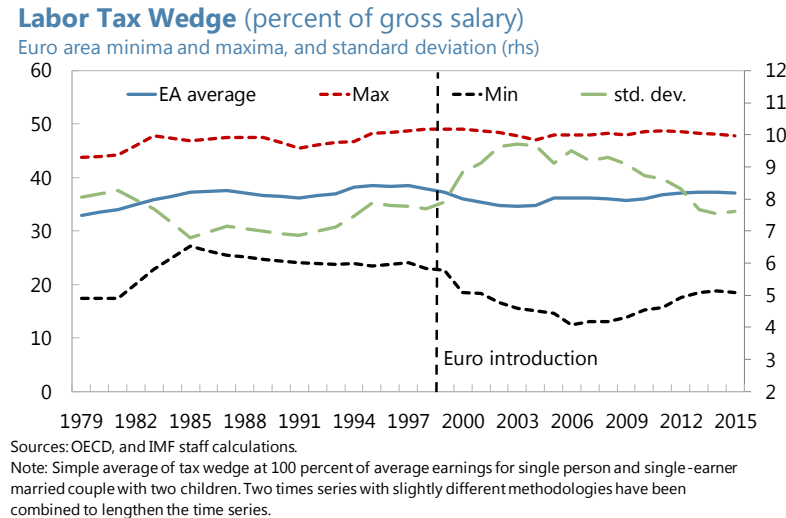

married couple with two children. Two times series with slightly different methodologies have been
combined to lengthen the time series.

\section{Widening competitiveness gaps led to the buildup of external imbalances within the}

euro area. In many countries, wage growth outpaced productivity growth, contributing to a build-up of competitiveness gaps (text chart), as manifest in persistent inflation differentials and divergent real effective exchange rates. More competitive economies such as Germany experienced widening current account surpluses, while countries with weaker productivity growth and higher inflation such as Spain saw widening deficits. Limited labor market flexibility compounded the competitiveness problem and increased the burden of adjustment following the crisis. The adjustment of imbalances since 2008 has been highly asymmetric, with current account deficits falling substantially in crisis countries - in large part as a result of import contraction - while surplus countries have not adjusted and in some cases have even seen their imbalances rise further (text chart) (Tressel et al., 2014).

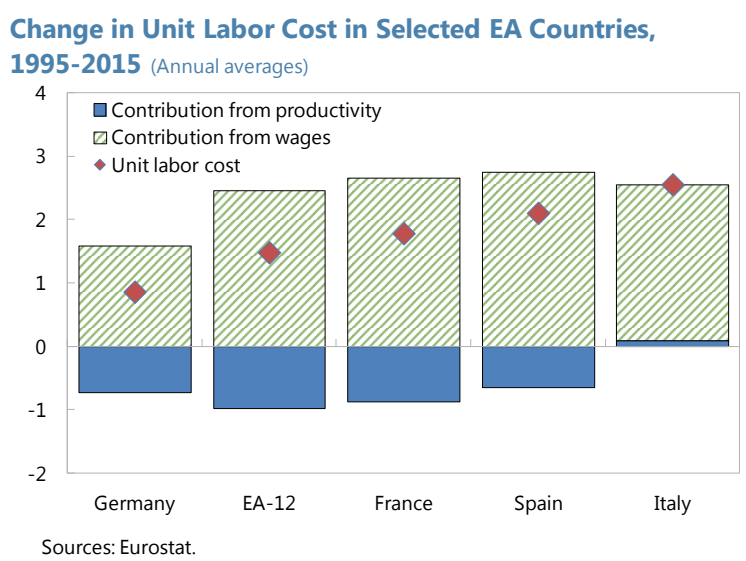

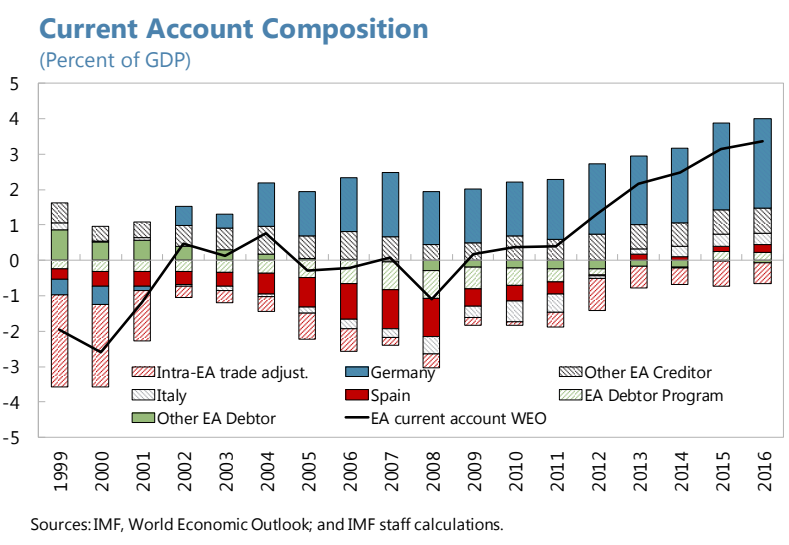




\section{Capital flow-driven boom-bust dynamics ultimately contributed to imbalances and real} economic divergence. By supplying exuberant investment in low-productivity sectors, precrisis capital flows exacerbated economic disequilibria in the form of misalignments between productivity and compensation, which undermined incentives for efficient resource allocation and sustainable growth. ${ }^{24}$ The retrenchment of cross-border bank lending further weakened periphery banks' balance sheets and reinforced the credit crunch, hindering the reallocation of labor and capital. ${ }^{25}$ In hindsight, the financial imbalances linked to

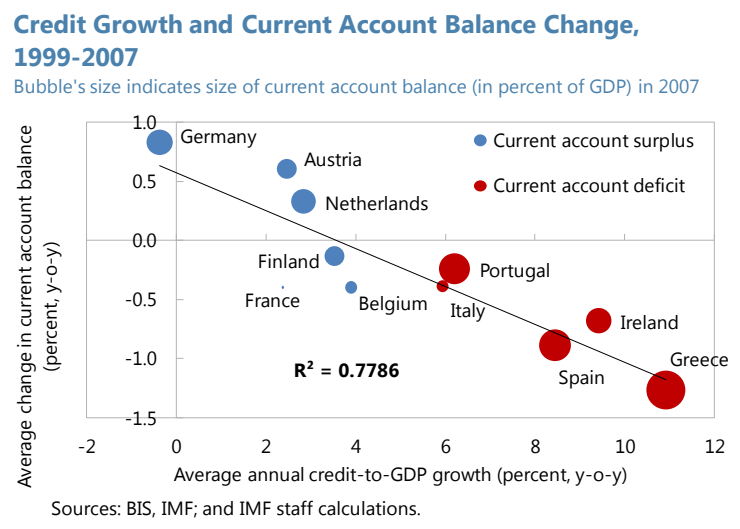
the different positions of countries' financial cycles created unsustainable booms and large current account imbalances (text chart), encouraged pro-cyclical fiscal policy in recipient countries, and contributed to resource misallocation, thereby lowering potential output. ${ }^{26}$

Finally, fiscal policy tended to exacerbate the cycles. The Stability and Growth Pact (SGP) was meant to prevent national fiscal policies from producing negative spillovers on other countries and on the conduct of monetary policy. However, the SGP framework did not fully prevent pro-cyclical fiscal policies before the crisis. In addition, compliance with the SGP rules was weak and the complexity of the framework has hampered effective monitoring (Eyraud and $\mathrm{Wu}, 2015$ ). As a result, most countries had built insufficient fiscal buffers in good times, which forced them to undertake large consolidations in an exceptional downturn (text charts). By exacerbating the economic cycle in some countries, fiscal policies likely contributed to the growing differences in business cycle amplitudes observed across euro area countries since the crisis. Finally, the absence of a common fiscal capacity significantly limited the ability to conduct countercyclical fiscal policy and cushion asymmetric shocks within the EMU (see Box 1 for a comparison with the US).

\footnotetext{
${ }^{24}$ Borio et al. (2015) provide evidence that credit booms lead to aggregate productivity slowdowns through more rapid expansion of employment in construction, which is a structurally low productivity growth sector. Adler et al. (2017) find that the credit boom and the financial crisis that followed undermined the efficiency of capital allocation both within and across firms.

${ }^{25}$ For Spain, and Southern European countries in general, there is evidence of increasing within-sector capital misallocation, accounting for the negative productivity growth during the pre-crisis credit boom (Gopinath et al., 2015, García-Santana et al., 2016). Conversely, there is evidence of healthier capital reallocation in Spain since the crisis, partly due to banks discriminating better among firms when granting loans (Blanco and Jiménez, 2016).

${ }^{26}$ See Budina et a. (2015) for a discussion of the interlinkages between financial cycles and fiscal policies.
} 

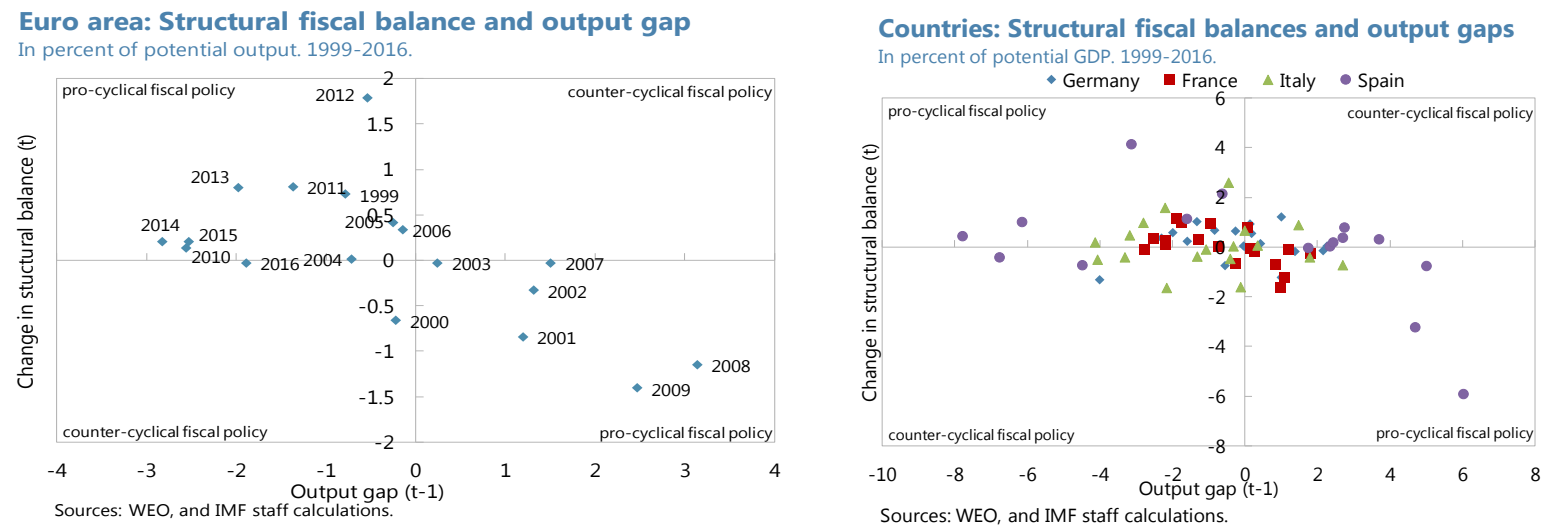
Box 1. Real Income Convergence Across U.S. States

Updating Barro and Sala-i-Martin (1992), U.S. states continue to show clear evidence of convergence. Using data for personal income per capita since 1929 , a more adequate time horizon for convergence analysis, we find that poorer U.S. states grew faster than richer ones ( $\beta$-convergence) and that income dispersion was reduced considerably until the 1970s, remaining flat thereafter ( $\sigma$-convergence).

The U.S. and the euro area are naturally not directly comparable, as the U.S. is a federation, and has greater labor mobility. Nevertheless, it is likely that the strong income convergence across U.S. states is supported by fiscal transfers. According to Sørensen and Yosha (1998), the U.S. federal budget smooths around 15 percent of idiosyncratic shocks to state incomes.

Interestingly, however, income dispersion across U.S. states is in the same ball park as dispersion across euro area countries. The coefficient of variation across U.S. states is currently 0.17 , above the lowest level of EA-12 countries in 1998 (0.15), but below its current level $(0.26)$. This suggests that income convergence may not be crucial for a well-functioning monetary union, in particular if fiscal transfers are allowed to smoothen the impact of asymmetric shocks.
$\beta$-Convergence Across U.S. States, 1929-2014

(Per capita personal income)

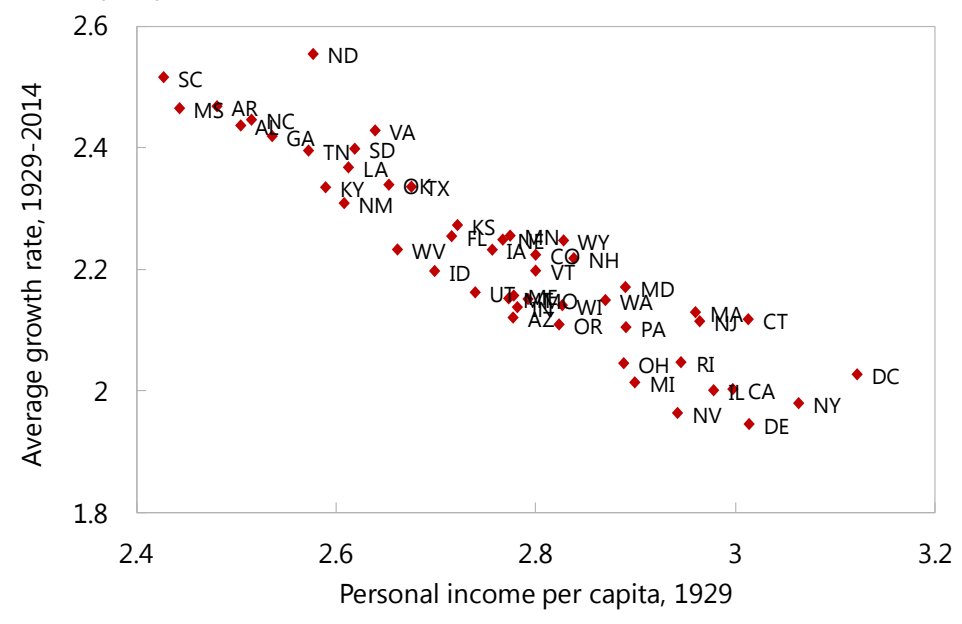

Sources: U.S. Bureau of Economic Analysis.

$\sigma$-Convergence Across U.S. States 1929-2014

(Per capita personal income)

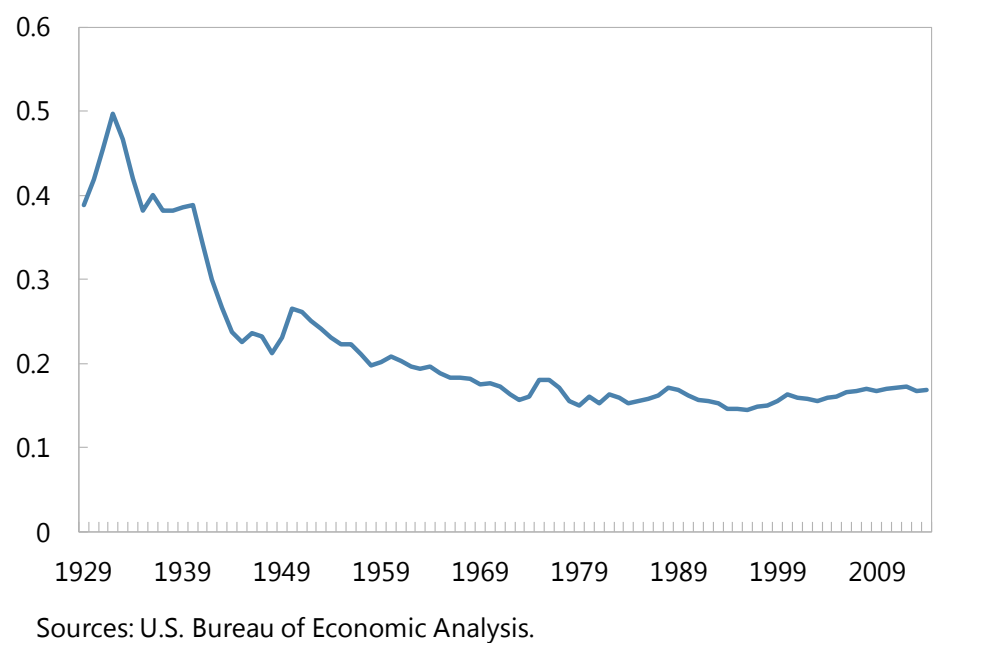




\section{Policies To Stabilize Business and Financial CyCles and Deliver More CONVERGENCE}

The architecture of the euro area has already been fortified as a response to the crisis, to prevent unsustainable booms and improve the resilience to shocks. First, with the Banking Union, euro area countries now have a single rulebook, common supervision and resolution mechanisms, which are better suited to oversee an integrated financial system and address cross-border build-up of risks. Actions to bolster financial stability at the global level, such as strengthening capital and liquidity standards and addressing banks that are too big to fail, have also contributed to building a safer financial sector. Second, the Macroeconomic Imbalances Procedure has increased the potential to identify and address macroeconomic imbalances that could adversely affect economic stability in a euro area country or the euro area as a whole. Third, the Two-Pack and the Six-Pack have strengthened the monitoring and coordination of fiscal policies across euro area countries. Finally, the creation of a common firewall - the European Stability Mechanism - the euro area is better equipped to address severe financial stress in its member countries and prevent spillovers.

To strengthen the monetary union further, policies should promote stability over the cycle by strengthening the adjustment mechanisms, and aim to re-start income convergence. In the face of large differences in the amplitude of business cycles, together with strong and sometimes divergent financial cycles, euro area countries need sufficiently flexible economic structures as well as more prudent national fiscal policies complemented by joint counter-cyclical instruments, to avoid relying excessively on the common monetary policy to prevent and dampen shocks and unsustainable financial flows. At the same time, greater real income convergence through productivity-enhancing reforms is crucial to sustain political support for the euro.

Common fiscal mechanisms could play an important role in macroeconomic

stabilization. Despite synchronized business cycles in the euro area, asymmetric shocks will still occur. Moreover, as we have shown, even synchronized cycles can vary in intensity across countries, requiring differentiated responses. In line with the OCA theory, with a common monetary policy, a central fiscal capacity would provide countries with more flexibility in responding to such asymmetric shocks, cushioning the impact of the required internal devaluation. It would permit a more accommodative fiscal stance in a downturn, while supporting fiscal discipline in good times (IMF, 2017b). Any new central fiscal capacity should be complemented by reforms of the existing fiscal rules, making them simpler, more countercyclical in practice, and strengthening monitoring and compliance (IMF, 2016a; IMF, 2016b).

Expanded centrally-financed EU investment could raise potential growth in lagging countries (IMF, 2017b). As noted in IMF (2014), higher public infrastructure investment through mechanisms such as EFSI and structural funds could raise growth in the short term 
by boosting aggregate demand in a downturn and in the long term by increasing productive capacity.

Greater efforts are needed to improve structural flexibility and close competitiveness gaps. Structural reforms would enhance countries' capacity to adjust to shocks, but would also help improve productivity growth in lagging countries to strengthen competitiveness and ultimately foster income convergence, as suggested in IMF (2017c). Reforms at the EU level, such as facilitating cross-border service delivery and the portability of pension claims, can help to increase the flexibility and competitiveness of the single market, in addition to more effective use of EU financial instruments. However, the main responsibility for reviving productivity growth rests at the national level. Empirical research has shown that structural reforms play an essential role in boosting productivity growth (Adler et al., 2017).

Furthermore, Banerji et al. (2017) shows that labor and product market reforms have a larger impact on productivity growth in countries with low initial productivity levels, thereby providing an important tool to restart convergence. Introducing outcome-based benchmarks and providing greater incentives for structural reforms for euro area countries could contribute to advancing necessary reforms at the national level (Banerji et al., 2015).

Sustainable income convergence would bolster the political stability of the monetary union. While divergence may be less worrying in times of high growth, the prospects of persistent low growth reinforces the political economy implications of income divergence. The experience from the first decades of the monetary union shows that income convergence is difficult to achieve. The increase in capital flows after the euro introduction led to misallocation of capital, which triggered boom-bust cycles. More sustainable income convergence would be facilitated by greater macroeconomic stability, but should be driven mainly by productivity growth. Productivity growth requires greater capital investment, including in human capital, better allocated to growth -enhancing areas. Ultimately, greater income convergence can help strengthen both the support for the monetary union and strengthen countries' resilience to shocks, thereby alleviating concerns about permanent transfers from richer to poorer countries.

Differences in the amplitude of financial cycles highlight the need for country-specific macro-prudential policies and system-wide surveillance in guarding against the buildup of systemic risk. Country-specific macro-prudential measures, in combination with a strong micro-prudential framework, have an important role in taming the build-up of excessive leverage and credit booms in order to improve capital allocation and prevent financial busts. The Banking Union has improved financial sector oversight, including for cross-border activities, but still lacks the critical common backstop and deposit insurance. Such cross-country, credible backstops could help prevent large downturns, by reducing the incentives for fire sales, and are essential to complete the Banking Union. 


\section{Conclusions}

\section{Euro area economies have not converged as envisaged on important dimensions:}

- Nominal convergence of inflation and interest rates largely took place in the run-up to the establishment of the euro. It was temporarily reversed during the recent financial crisis, but has since been reestablished. However, greater convergence of interest rates than inflation produced lower real interest rates during the early years of monetary union, helping to fuel unsustainable capital inflows into lower income countries.

- Real convergence has not occurred among the original euro members. GDP growth and productivity growth have not reduced income disparities between richer and poorer countries. While there was some convergence of unemployment rates, it has been partially reversed since the economic crisis. In contrast, there has been significant convergence among those countries who have since joined the euro.

- The synchronization of the timing of business cycles has improved, but the amplitude of those cycles has diverged, complicating the calibration of the common monetary policy.

- The synchronization of the timing of financial cycles diverged during the pre-crisis boom, but has since been reestablished. German financial cycles, however, have become more delinked from the rest. As with business cycles, the amplitude of financial cycles has become more uneven. Large capital flows to less advanced economies played a strongly pro-cyclical role, contributing to the build-up of internal and external imbalances and systemic risk, as well as resource misallocation and therefore productivity divergence.

Monetary union successfully established a credible monetary policy framework with low inflation and a stable exchange rate, and increased business and financial cycle synchronization, but stronger policies to help cushion divergent shocks are needed to improve economic performance. Important actions have already been taken in establishing the Banking Union, monitoring and coordinating macroeconomic policies more closely, and pushing for greater structural reforms through the European Semester, Macroeconomic Imbalances Procedure, and other initiatives. However, additional efforts are needed. Recalibrated euro area fiscal rules to allow for greater countercyclical policies, together with a common fiscal capacity, could give countries space to effectively dampen business cycles, reducing amplitude variations. Completion of the Banking Union, Capital Markets Union, and greater use of macro-prudential regulations could help synchronize and smooth the amplitude of financial cycles, although it is unclear if this would remedy the financial cycle divergence of Germany. Greater structural reform is needed to improve productivity growth and to allow countries to respond more readily to heterogeneous economic shocks. National governments have thus far only made limited progress in improving flexibility, suggesting a role for larger euro area-wide benchmarks and greater incentives. 
Ultimately, greater convergence of income levels is important to share the benefits of monetary union to all European citizens. Greater convergence of macroeconomic cycles can help, as macroeconomic policies will be more optimal more of the time. For this, the recent divergence of productivity growth rates must be reversed. Improved structural policies in lagging countries can help, but investments to improve capital investment, worker education and training, and research and development would also be important. 


\section{APPENDIX: BUSINESS CYCLE AND FINANCIAL CYCLE ANALYSIS: METHODOLOGY AND DETAILED RESUlts}

\section{Business cycle and financial cycle measurement}

Business cycle. Following Drehmann et al. (2012), the bandpass filter developed by Christiano and Fitzgerald (2003) is used to measure the business cycle, defined as the shortterm cyclical component of real, seasonally-adjusted GDP, normalized to Q1 1985 for unit comparability. Following Comin and Gertler (2006), the duration of short-term cycles is set at 5 to 32 quarters.

Financial cycle. The financial cycle is estimated as in Drehmann et al. (2012), by a multivariate frequency-based filter, in year-on-year percentage change, applied to the creditto-GDP ratio, credit to the non-financial private sector, and residential property prices (all normalized to 1985Q1 for unit comparability) for EA-12 countries except Luxembourg. All time series come from the BIS. Credit and residential property prices are in real terms (deflated by CPI in annual growth rates, from the OECD's Main Economic Indicators) and in four-quarter differences in log levels. The financial cycle is defined by the average of the medium-term cyclical component of the three time-series. Although the literature on financial cycle measurement is still new, the methodology proposed by Drehmann et al. (2012) is the most standard with the focus on credit, credit-to-GDP, and residential property prices as the most relevant financial variables to capture key macro-financial dynamics (Stremmel and Zsámboki, 2015, Schüler et al., 2016).

The bandpass filter developed by Christiano and Fitzgerald (2003) is used to separate time series into a trend and a cyclical component at specific frequency intervals. There is support from the literature on the use of the bandpass filter (Stremmel, 2015). A further reason for the choice of the bandpass filter are the well-known shortcomings of the alternative HP filter (Hamilton, 2016). Short- and medium-term cycles are defined in order to isolate cyclical patterns with short and longer periodicity. Following Comin and Gertler (2006) and Drehmann et al. (2012), their duration is set at 5 to 32 quarters and 32 to 120 quarters, respectively.

The countries in the sample are divided into a "high-amplitude" group and a "low-amplitude" group. The high-amplitude group is composed of countries whose financial cycles have a standard deviation that is higher than the average standard deviation for all countries in the sample for both the whole sample period (1971-2015) and the euro period (1999-2015). This group includes Ireland, Greece, and Spain, while the low-amplitude group includes Germany, France, Italy, Netherlands, Austria, Finland, and Portugal. A GDP-weighted average financial cycle is calculated for each group using GDP data from the OECD Quarterly National Accounts, in US dollars, volume estimates, fixed PPPs, seasonally adjusted. 
Residential property price data do not extend far enough in time for three countries (Austria, Portugal and Greece), and are therefore excluded from their financial cycle measure.

Nevertheless, residential property price data from the Bank of Greece suggest that Greece experienced a pronounced housing price boom between 1995 and 2008. This suggests that, although Greece qualifies as a high-amplitude country, the amplitude of its financial cycle is in fact underestimated.

\section{Cyclical synchronization measurement}

Two statistics are calculated to measure the degree of synchronization of business cycles and financial cycles: the concordance statistic and the growth differential.

Concordance statistic. The concordance statistic measures the degree of co-movement between cycles. Following Harding and Pagan (2002), the concordance statistic, $C_{x y}$, for variables $\mathrm{x}$ and $\mathrm{y}$ is defined as:

$$
C I_{x y}=\frac{1}{T} \sum_{t=1}^{T}\left[C_{t}^{x} \cdot C_{t}^{y}+\left(1-C_{t}^{x}\right) \cdot\left(1-C_{t}^{y}\right)\right]
$$

where

$$
\begin{aligned}
& C_{t}^{x}=\{0, \text { if } x \text { is in recession phase at time } t ; 1, \text { if } x \text { is in expansion phase at time } t\} \\
& C_{t}^{y}=\{0, \text { if } y \text { is in recession phase at time } t ; 1 \text {,if } y \text { is in expansion phase at time } t\}
\end{aligned}
$$

The concordance static is therefore comprised between 0 and 1, corresponding to the fraction of time that two series are in the same phase of their respective cycles. The series are fully pro-cyclical (countercyclical) if the concordance statistic is equal to one (zero).

Growth differential. The growth differential measures the discrepancy between two cycles, independently of whether these cycles are in the same phase or not. The growth differential complements the concordance statistic, as there can be significant differences in cyclical positions even when national cycles are highly correlated (Belke et al. 2016). Whereas the concordance statistic provides information on the duration dimension of correlation, the growth differential sheds light on amplitude, and has the added advantage of being invariant to the volatility of the underlying shock.

Following Cesa-Bianchi et al. (2016), the absolute differential in GDP or financial cycle growth $S_{i j, t}$, is defined as:

$$
S_{i j, t}=-\left|y_{i, t}-y_{j, t}\right|
$$


where $y_{i, t}$ and $y_{j, t}$ are the growth rates of GDP or financial cycles in countries $i$ and $j$ at time $t$.

A negative growth differential close to zero indicates a small cyclical discrepancy. The more negative the growth differential, the larger the discrepancy between the two cyclical positions.

Both the concordance statistic and the growth differential are measured for the each of the 55 country pairs in the sample. Summary statistics for all country pairs are assembled. The concordance statistic and growth differential are also used to measure the degree of synchronization between each country's business cycle and financial cycle.

The sample period is broken down into three sub-periods: 1971:1-1998:2 (pre-euro area period), 1999:1-2007:1 (pre-crisis euro period), and 2007:2-2015:1 (euro area crisis period). The choice of period bounds is justified by the paper's focus on the convergence experience under EMU, which provides a natural break at the introduction of the euro (1999:1). Q1 2007 is chosen due to the fact that many euro area countries' business cycles (and several housing price booms) peaked around H1 2007, and that the turmoil of the global financial crisis started around mid-2007.

A drawback of analyzing the period 2007:2-2015:1 as a block is that the crisis phase and the institutional changes introduced after 2011 are lumped together. On the other hand, this breakdown allows for a sufficient number of quarters in each period to generate statistically meaningful results, and for the EMU periods to contain a comparable number of quarters. 


\section{Detailed Results}

Appendix Table 1: Concordance of Business Cycles, 1971q2-1998q4

(Bilateral concordance statistics of business cycle components in euro area countries)

\begin{tabular}{|c|c|c|c|c|c|c|c|c|c|c|c|c|c|}
\hline & AUT & BEL & FIN & FRA & DEU & GRC & IRL & ITA & NTL & PRT & ESP & Mean & $\begin{array}{c}\text { GDP- } \\
\text { weighted } \\
\text { mean }\end{array}$ \\
\hline AUT & 1.00 & & & & & & & & & & & & \\
\hline BEL & 0.59 & 1.00 & & & & & & & & & & & \\
\hline FIN & 0.58 & 0.53 & 1.00 & & & & & & & & & & \\
\hline FRA & 0.54 & 0.75 & 0.55 & 1.00 & & & & & & & & & \\
\hline DEU & 0.77 & 0.62 & 0.57 & 0.60 & 1.00 & & & & & & & & \\
\hline GRC & 0.48 & 0.76 & 0.50 & 0.63 & 0.56 & 1.00 & & & & & & & \\
\hline IRL & 0.38 & 0.53 & 0.50 & 0.50 & 0.42 & 0.56 & 1.00 & & & & & & \\
\hline ITA & 0.64 & 0.81 & 0.52 & 0.77 & 0.65 & 0.64 & 0.43 & 1.00 & & & & & \\
\hline NLD & 0.72 & 0.68 & 0.53 & 0.66 & 0.75 & 0.54 & 0.42 & 0.61 & 1.00 & & & & \\
\hline PRT & 0.68 & 0.59 & 0.63 & 0.59 & 0.65 & 0.50 & 0.47 & 0.53 & 0.56 & 1.00 & & & \\
\hline ESP & 0.59 & 0.62 & 0.59 & 0.68 & 0.57 & 0.59 & 0.48 & 0.63 & 0.59 & 0.63 & 1.00 & & \\
\hline Mean & 0.60 & 0.65 & 0.55 & 0.63 & 0.62 & 0.58 & 0.47 & 0.62 & 0.61 & 0.58 & 0.60 & 0.59 & 0.61 \\
\hline
\end{tabular}

Appendix Table 2: Concordance of Business Cycles, 1999q1-2007q1

(Bilateral concordance statistics of business cycle components in euro area countries)

\begin{tabular}{|c|c|c|c|c|c|c|c|c|c|c|c|c|c|}
\hline & AUT & BEL & FIN & FRA & DEU & GRC & IRL & ITA & NTL & PRT & ESP & Mean & $\begin{array}{c}\text { GDP- } \\
\text { weighted } \\
\text { mean }\end{array}$ \\
\hline AUT & 1.00 & & & & & & & & & & & & \\
\hline BEL & 0.82 & 1.00 & & & & & & & & & & & \\
\hline FIN & 0.61 & 0.67 & 1.00 & & & & & & & & & & \\
\hline FRA & 0.70 & 0.76 & 0.73 & 1.00 & & & & & & & & & \\
\hline DEU & 0.70 & 0.70 & 0.61 & 0.82 & 1.00 & & & & & & & & \\
\hline GRC & 0.61 & 0.61 & 0.58 & 0.61 & 0.55 & 1.00 & & & & & & & \\
\hline IRL & 0.76 & 0.64 & 0.48 & 0.64 & 0.70 & 0.61 & 1.00 & & & & & & \\
\hline ITA & 0.79 & 0.79 & 0.64 & 0.79 & 0.79 & 0.64 & 0.67 & 1.00 & & & & & \\
\hline NLD & 0.79 & 0.73 & 0.39 & 0.67 & 0.67 & 0.52 & 0.61 & 0.70 & 1.00 & & & & \\
\hline PRT & 0.52 & 0.58 & 0.85 & 0.64 & 0.64 & 0.55 & 0.45 & 0.61 & 0.36 & 1.00 & & & \\
\hline ESP & 0.52 & 0.52 & 0.55 & 0.58 & 0.64 & 0.73 & 0.58 & 0.73 & 0.55 & 0.58 & 1.00 & & \\
\hline Mean & 0.68 & 0.68 & 0.61 & 0.69 & 0.68 & 0.60 & 0.61 & 0.71 & 0.60 & 0.58 & 0.59 & 0.64 & 0.66 \\
\hline
\end{tabular}


Appendix Table 3: Concordance of Business Cycles, 2007q2-2015q1

(Bilateral concordance statistics of business cycle components in euro area countries)

\begin{tabular}{|c|c|c|c|c|c|c|c|c|c|c|c|c|c|}
\hline & AUT & BEL & FIN & FRA & DEU & GRC & IRL & ITA & NTL & PRT & ESP & Mean & $\begin{array}{c}\text { GDP- } \\
\text { weighted } \\
\text { mean }\end{array}$ \\
\hline AUT & 1.00 & & & & & & & & & & & & \\
\hline BEL & 0.75 & 1.00 & & & & & & & & & & & \\
\hline FIN & 0.63 & 0.75 & 1.00 & & & & & & & & & & \\
\hline FRA & 0.66 & 0.72 & 0.91 & 1.00 & & & & & & & & & \\
\hline DEU & 0.84 & 0.84 & 0.78 & 0.75 & 1.00 & & & & & & & & \\
\hline GRC & 0.56 & 0.69 & 0.56 & 0.59 & 0.59 & 1.00 & & & & & & & \\
\hline IRL & 0.88 & 0.81 & 0.75 & 0.78 & 0.91 & 0.56 & 1.00 & & & & & & \\
\hline ITA & 0.78 & 0.78 & 0.78 & 0.81 & 0.94 & 0.66 & 0.84 & 1.00 & & & & & \\
\hline NLD & 0.75 & 0.75 & 0.75 & 0.72 & 0.78 & 0.50 & 0.81 & 0.72 & 1.00 & & & & \\
\hline PRT & 0.66 & 0.78 & 0.84 & 0.75 & 0.81 & 0.66 & 0.72 & 0.81 & 0.72 & 1.00 & & & \\
\hline ESP & 0.63 & 0.81 & 0.88 & 0.78 & 0.78 & 0.56 & 0.75 & 0.72 & 0.88 & 0.78 & 1.00 & & \\
\hline Mean & 0.71 & 0.77 & 0.76 & 0.75 & 0.80 & 0.59 & 0.78 & 0.78 & 0.74 & 0.75 & 0.76 & 0.75 & 0.77 \\
\hline
\end{tabular}

Appendix Table 4: Concordance of Financial Cycles, 1971q2-1998q4

(Bilateral concordance statistics of financial cycle components in euro area countries)

\begin{tabular}{|c|c|c|c|c|c|c|c|c|c|c|c|c|c|}
\hline & AUT & BEL & FIN & FRA & DEU & GRC & IRL & ITA & NTL & PRT & ESP & Mean & $\begin{array}{c}\text { GDP- } \\
\text { weighted } \\
\text { mean }\end{array}$ \\
\hline AUT & 1.00 & & & & & & & & & & & & \\
\hline BEL & 0.73 & 1.00 & & & & & & & & & & & \\
\hline FIN & 0.66 & 0.62 & 1.00 & & & & & & & & & & \\
\hline FRA & 0.86 & 0.70 & 0.72 & 1.00 & & & & & & & & & \\
\hline DEU & 0.82 & 0.57 & 0.62 & 0.77 & 1.00 & & & & & & & & \\
\hline GRC & 0.74 & 0.49 & 0.56 & 0.62 & 0.74 & 1.00 & & & & & & & \\
\hline IRL & 0.80 & 0.82 & 0.57 & 0.67 & 0.68 & 0.61 & 1.00 & & & & & & \\
\hline ITA & 0.63 & 0.58 & 0.79 & 0.71 & 0.70 & 0.55 & 0.56 & 1.00 & & & & & \\
\hline NLD & 0.70 & 0.90 & 0.59 & 0.62 & 0.54 & 0.53 & 0.83 & 0.48 & 1.00 & & & & \\
\hline PRT & 0.47 & 0.41 & 0.65 & 0.55 & 0.63 & 0.55 & 0.41 & 0.80 & 0.32 & 1.00 & & & \\
\hline ESP & 0.66 & 0.86 & 0.73 & 0.76 & 0.55 & 0.41 & 0.69 & 0.65 & 0.81 & 0.49 & 1.00 & & \\
\hline Mean & 0.71 & 0.67 & 0.65 & 0.70 & 0.66 & 0.58 & 0.66 & 0.65 & 0.63 & 0.53 & 0.66 & 0.65 & 0.66 \\
\hline
\end{tabular}


Appendix Table 5: Concordance of Financial Cycles, 1999q1-2007q1

(Bilateral concordance statistics of financial cycle components in euro area countries)

\begin{tabular}{|c|c|c|c|c|c|c|c|c|c|c|c|c|c|}
\hline & AUT & BEL & FIN & FRA & DEU & GRC & IRL & ITA & NTL & PRT & ESP & Mean & $\begin{array}{c}\text { GDP- } \\
\text { weighted } \\
\text { mean }\end{array}$ \\
\hline AUT & 1.00 & & & & & & & & & & & & \\
\hline BEL & 0.94 & 1.00 & & & & & & & & & & & \\
\hline FIN & 0.85 & 0.85 & 1.00 & & & & & & & & & & \\
\hline FRA & 0.24 & 0.24 & 0.39 & 1.00 & & & & & & & & & \\
\hline DEU & 0.55 & 0.61 & 0.45 & 0.27 & 1.00 & & & & & & & & \\
\hline GRC & 0.79 & 0.79 & 0.94 & 0.45 & 0.39 & 1.00 & & & & & & & \\
\hline IRL & 0.85 & 0.79 & 0.76 & 0.33 & 0.39 & 0.76 & 1.00 & & & & & & \\
\hline ITA & 0.52 & 0.52 & 0.67 & 0.73 & 0.12 & 0.73 & 0.61 & 1.00 & & & & & \\
\hline NLD & 0.79 & 0.85 & 0.70 & 0.09 & 0.76 & 0.64 & 0.64 & 0.36 & 1.00 & & & & \\
\hline PRT & 0.70 & 0.76 & 0.79 & 0.18 & 0.67 & 0.73 & 0.55 & 0.45 & 0.91 & 1.00 & & & \\
\hline ESP & 0.33 & 0.33 & 0.48 & 0.91 & 0.18 & 0.55 & 0.42 & 0.82 & 0.18 & 0.27 & 1.00 & & \\
\hline Mean & 0.65 & 0.67 & 0.69 & 0.38 & 0.44 & 0.68 & 0.61 & 0.55 & 0.59 & 0.60 & 0.45 & 0.57 & 0.49 \\
\hline
\end{tabular}

Appendix Table 6: Concordance of Financial Cycles, 2007q2-2015q1

(Bilateral concordance statistics of financial cycle components in euro area countries)

\begin{tabular}{|c|c|c|c|c|c|c|c|c|c|c|c|c|c|}
\hline & AUT & BEL & FIN & FRA & DEU & GRC & IRL & ITA & NTL & PRT & ESP & Mean & $\begin{array}{c}\text { GDP- } \\
\text { weighted } \\
\text { mean }\end{array}$ \\
\hline AUT & 1.00 & & & & & & & & & & & & \\
\hline BEL & 0.81 & 1.00 & & & & & & & & & & & \\
\hline FIN & 0.94 & 0.81 & 1.00 & & & & & & & & & & \\
\hline FRA & 0.94 & 0.75 & 0.94 & 1.00 & & & & & & & & & \\
\hline DEU & 0.38 & 0.38 & 0.31 & 0.31 & 1.00 & & & & & & & & \\
\hline GRC & 0.75 & 0.81 & 0.75 & 0.69 & 0.19 & 1.00 & & & & & & & \\
\hline IRL & 0.94 & 0.88 & 0.94 & 0.88 & 0.31 & 0.81 & 1.00 & & & & & & \\
\hline ITA & 0.91 & 0.78 & 0.97 & 0.97 & 0.28 & 0.72 & 0.91 & 1.00 & & & & & \\
\hline NLD & 0.94 & 0.88 & 0.94 & 0.88 & 0.38 & 0.81 & 0.94 & 0.91 & 1.00 & & & & \\
\hline PRT & 0.50 & 0.69 & 0.50 & 0.44 & 0.31 & 0.75 & 0.56 & 0.47 & 0.56 & 1.00 & & & \\
\hline ESP & 0.91 & 0.72 & 0.91 & 0.97 & 0.34 & 0.66 & 0.84 & 0.94 & 0.84 & 0.41 & 1.00 & & \\
\hline Mean & 0.80 & 0.75 & 0.80 & 0.78 & 0.32 & 0.69 & 0.80 & 0.78 & 0.81 & 0.52 & 0.75 & 0.71 & 0.64 \\
\hline
\end{tabular}


Appendix Table 7: Concordance of low-amplitude countries' financial cycles with those of high-amplitude countries

\begin{tabular}{|l|c|c|c|c|}
\hline & $1971-1998$ & $1999-2007$ & $2007-2015$ & $1999-2015$ \\
\hline AUT & 0.73 & 0.66 & 0.86 & 0.75 \\
\hline BEL & 0.72 & 0.64 & 0.80 & 0.72 \\
\hline FRA & 0.62 & 0.73 & 0.86 & 0.74 \\
\hline DEU & 0.68 & 0.57 & 0.84 & 0.70 \\
\hline ITA & 0.65 & 0.32 & 0.28 & 0.42 \\
\hline NLD & 0.59 & 0.72 & 0.85 & 0.72 \\
\hline PRT & 0.72 & 0.52 & 0.86 & 0.70 \\
\hline Mean & 0.48 & 0.52 & 0.57 & 0.52 \\
\hline Mean (ex. & 0.65 & 0.58 & 0.74 & \\
\hline Germany) & 0.65 & 0.62 & 0.81 & \\
\hline
\end{tabular}

Appendix Table 8: Financial cycle growth differential relative to high-amplitude countries' financial cycles

\begin{tabular}{l|c|c|c|c|}
\hline & $\mathbf{1 9 7 1 - 1 9 9 8}$ & $\mathbf{1 9 9 9 - 2 0 0 7}$ & $\mathbf{2 0 0 7 - 2 0 1 5}$ & $1999-2015$ \\
\hline AUT & -2.71 & -3.53 & -4.39 & -3.54 \\
\hline BEL & -3.41 & -3.50 & -4.36 & -3.76 \\
\hline FIN & -2.75 & -2.37 & -3.79 & -2.97 \\
\hline FRA & -2.60 & -2.94 & -5.24 & -3.60 \\
\hline DEU & -2.92 & -3.92 & -6.41 & -4.42 \\
\hline ITA & -3.37 & -2.57 & -3.91 & -3.28 \\
\hline PLT & -3.53 & -4.78 & -4.36 & -4.23 \\
\hline & -4.74 & -4.78 & -4.57 & -4.70 \\
\hline Mean & & & & \\
\hline Mean (ex. & -3.26 & -3.55 & -4.63 & \\
\hline
\end{tabular}




\section{Appendix Table 9: Concordance and Growth Differential between National Business Cycles and Financial Cycles}

\begin{tabular}{l|c|c|c|c|c|c|}
\hline & \multicolumn{2}{|c|}{ 1971-1998 } & \multicolumn{2}{c|}{$1999-2007$} & \multicolumn{2}{c|}{ 2007-2015 } \\
\hline & Concordance & $\begin{array}{l}\text { Growth } \\
\text { differential }\end{array}$ & Concordance & $\begin{array}{l}\text { Growth } \\
\text { differential }\end{array}$ & Concordance & $\begin{array}{l}\text { Growth } \\
\text { differential }\end{array}$ \\
\hline AUT & 0.51 & -1.67 & 0.67 & -1.03 & 0.44 & -2.60 \\
\hline BEL & 0.49 & -1.93 & 0.67 & -1.08 & 0.69 & -2.53 \\
\hline FIN & 0.54 & -1.92 & 0.67 & -2.46 & 0.69 & -3.20 \\
\hline FRA & 0.50 & -1.31 & 0.39 & -1.09 & 0.66 & -1.72 \\
\hline DEU & 0.58 & -0.96 & 0.52 & -1.54 & 0.34 & -1.90 \\
\hline GRC & 0.45 & -2.31 & 0.48 & -2.54 & 0.44 & -5.51 \\
\hline IRL & 0.49 & -2.11 & 0.45 & -3.49 & 0.63 & -8.19 \\
\hline ITA & 0.49 & -2.06 & 0.64 & -1.71 & 0.69 & -3.01 \\
\hline NLD & 0.53 & -2.33 & 0.61 & -2.45 & 0.69 & -3.36 \\
\hline PRT & 0.49 & -2.49 & 0.55 & -2.66 & 0.59 & -2.55 \\
\hline ESP & 0.45 & -1.97 & 0.48 & -4.30 & 0.66 & -5.81 \\
\hline \multirow{2}{*}{ Mean } & & & & & & -3.67 \\
\hline \multirow{2}{*}{$\begin{array}{l}\text { GDP- } \\
\text { weighted }\end{array}$} & 0.50 & -1.91 & 0.56 & -2.21 & 0.59 & -2.93 \\
\hline mean & 0.51 & -1.59 & 0.53 & -1.95 & 0.56 & \\
\hline
\end{tabular}




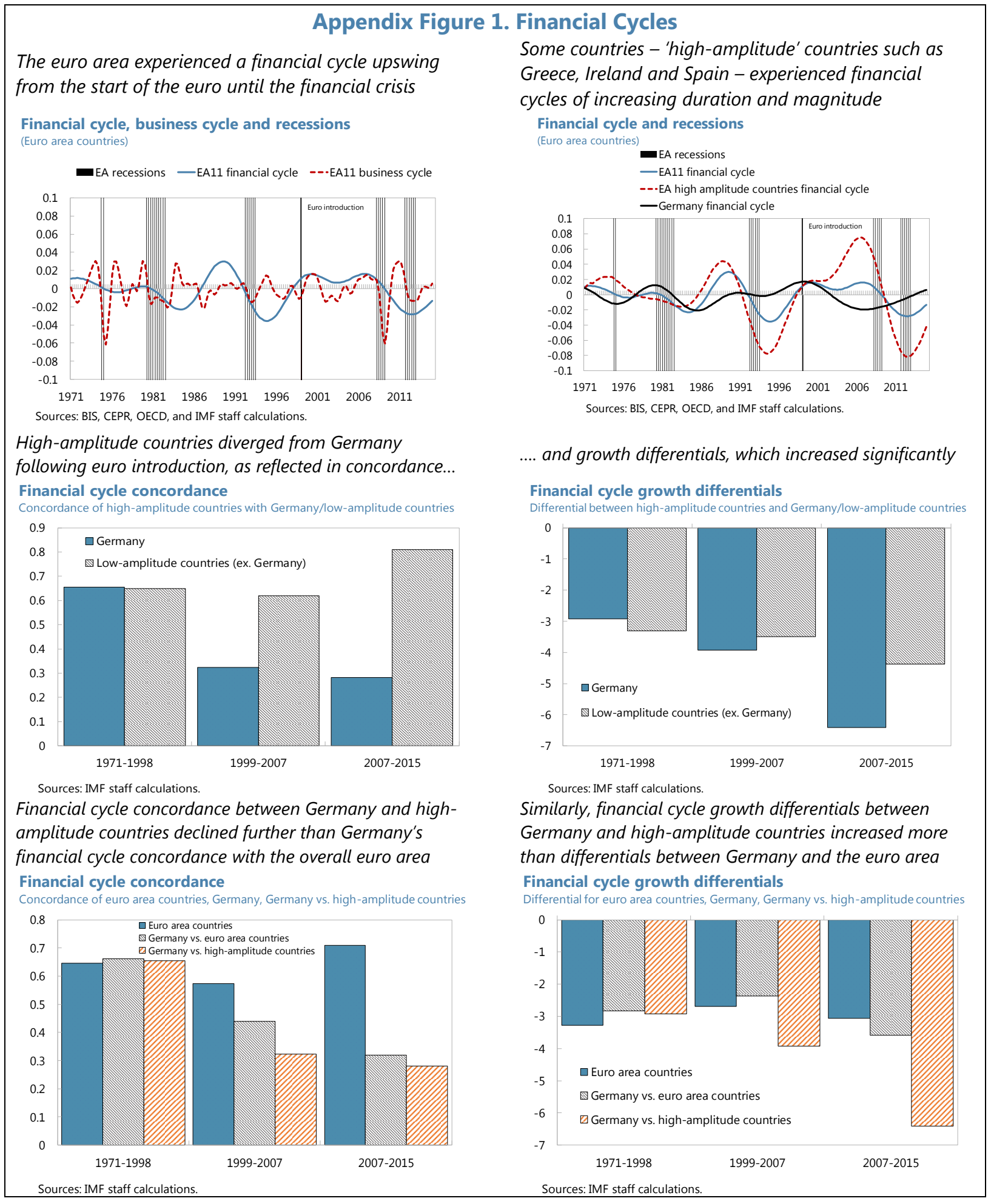

CInternational Monetary Fund. Not for Redistribution 


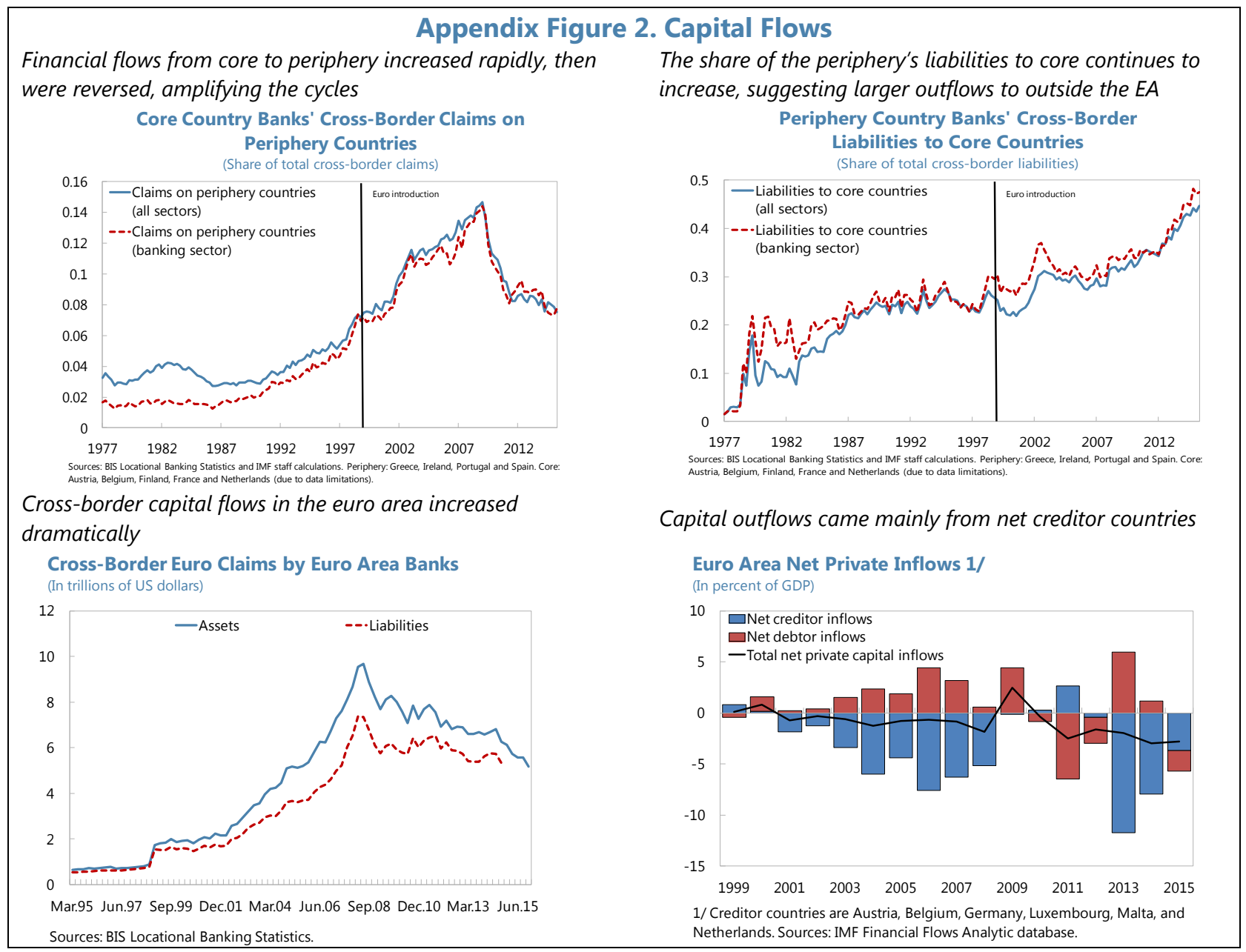

CInternational Monetary Fund. Not for Redistribution 


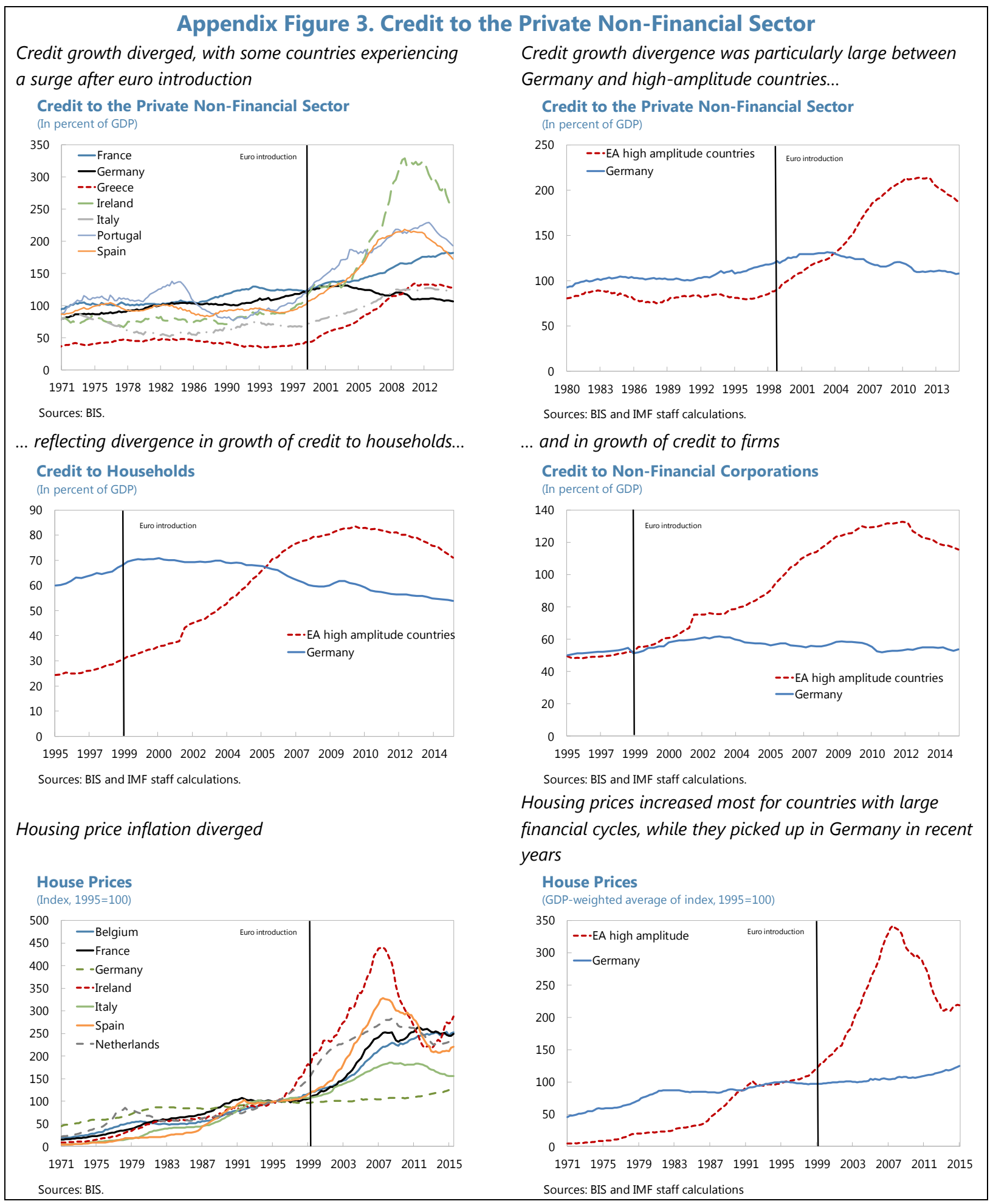

\section{CInternational Monetary Fund. Not for Redistribution}



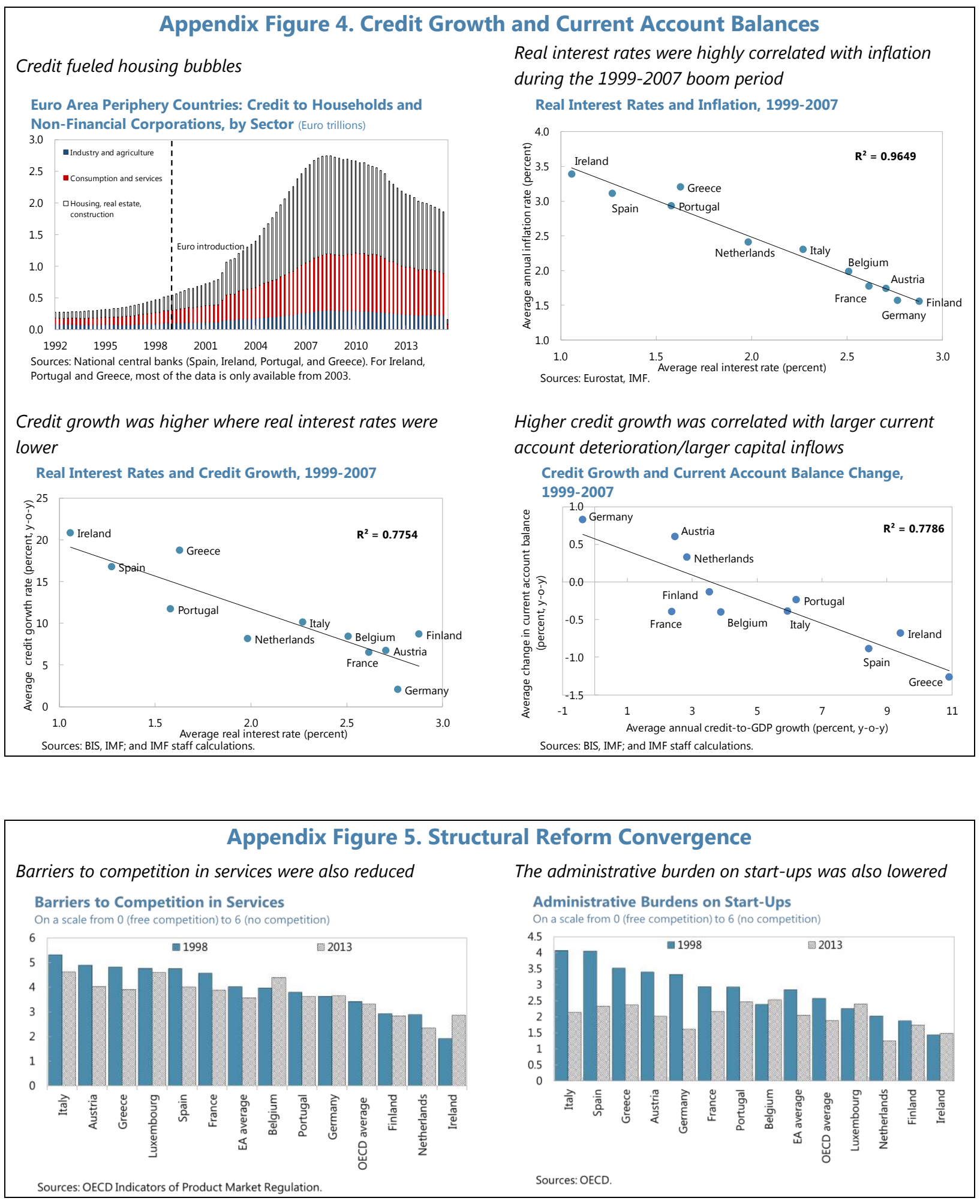

CInternational Monetary Fund. Not for Redistribution 


\section{References}

Adler, G., R. A. Duval, D. Furceri, S. Kiliç Çelik, K. Koloskova, and M. Poplawski-Ribeiro (2017), "Gone with the Headwinds: Global Productivity," IMF Staff Discussion Note, No. 17/04, dated April, International Monetary Fund.

Aglietta, M., and T. Brand (2013), Un New Deal pour l'Europe, Éditions Odile Jacob.

Aglietta, M., and N. Valla (2017), Macroéconomie financière, Éditions La Découverte.

Allard, C., P. Koeva Brooks, J. C. Bluedorn, F. Bornhorst, K. Christopherson, F. Ohnsorge, T. Poghosyan, et al. (2013), "Toward a Fiscal Union for the Euro Area," IMF Staff

Discussion Note, No. 13/09, dated September, International Monetary Fund.

Andrle, M., M. J. C. Bluedorn, L. Eyraud, M.T. Kinda, P.K. Brooks, M.G. Schwartz and A. Weber (2015), "Reforming fiscal governance in the European Union," IMF Staff Discussion Note, No. 15/19, dated May, International Monetary Fund.

auf dem Brinke, A., H. Enderlein, and J. Fritz-Vannahme (2015), What kind of convergence does the euro area need?, Gütersloh: Bertelsmann Stiftung and Jacques Delors Institut Berlin.

Banerji, A., B. Barkbu, J. John, T. Kinda, S. Saksonovs, H. Schoelermann, and T. Wu (2015), "Building a Better Union: Incentivizing Structural Reforms in the Euro Area," IMF Working Paper, No. 15/201, dated September, International Monetary Fund.

Barkbu, B., B. Eichengreen, and A. Mody (2016), “The Euro's Twin Challenges: Experience and Lessons," in J.A. Caporaso and M. Rhodes, Political and Economic Dynamics of the Eurozone Crisis, Oxford University Press.

Barro, R. J., and X. Sala-i-Martin (1992), "Convergence," Journal of Political Economy, Vol. 100, No. 2, pp. 223-251.

Bayoumi, T., and B. Eichengreen (1994), "One money or many? Analyzing the prospects for monetary unification in various parts of the world," Princeton Studies in International Finance, No. 76, dated September.

Bayoumi, T., and B. Eichengreen (forthcoming 2017), Aftershocks of Monetary Unification: Hysteresis with a Financial Twist.

Beck, G., K. Hubrich and M. Marcellino (2009), "Regional Inflation Dynamics Within and Across Euro Area Countries and a Comparison with the Unites States," Economic Policy, January 2009. 
Belke, A., C. Domnick, and D. Gros (2016), "Business Cycle Synchronization in the EMU: Core vs. Periphery,” CEPS Working Document, No. 427, dated November.

Benczes, I., and B. Szent-Ivanyi (2015), “The European Economy in 2014: Fragile Recovery and Convergence," Journal of Common Market Studies, Vol. 53 Annual review, pp. 162-180.

Bini-Smaghi, L., T. Padoa-Schioppa and F. Papadia (1993), "The Policy History of the Maastricht Treaty: The Transition to the Final Stage of EMU," in CEPR, The Monetary Future of Europe, Centre for Economic Policy Research, London.

Blanchard, O., and L.F. Katz (1992), "Regional evolutions," Brookings Papers on Economic Activity, Economic Studies Program, The Brookings Institution, Vol. 23, No. 1.

Blanchard, O., and F. Giavazzi (2002), "Current Account Deficits in the Euro Area: The End of the Feldstein-Horioka Puzzle?”, Brookings Papers on Economic Activity, 2002, No. 2, pp.147-209.

Blanco, R., and N. Jiménez (2016), "The role of the banking system in the credit reallocation process in the Spanish corporate sector over the recent business cycle," Box 2, pp. 242 in Investment and Investment Finance in Europe: Financing Productivity Growth, European Investment Bank.

Borio, C. (2014), “The financial cycle and macroeconomics: What have we learnt?”, Journal of Banking \& Finance, Vol. 45, pp 182-98.

Borio, C., E. Kharroubi, C. Upper, and F. Zampolli (2015), "Labour reallocation and productivity dynamics: financial causes, real consequences," BIS Working Papers, no. 534, dated December.

Budina, N., B. Gracia, X. Hu, and S. Saksonovs (2015), "Recognizing the Bias: Financial Cycles and Fiscal Policy," IMF Working Paper, No. 15/246, International Monetary Fund.

Buiter, W. H. (2006), "The 'Sense and Nonsense of Maastricht' Revisited: What Have We Learnt about Stabilization in EMU?" JCMS: Journal of Common Market Studies, Vol. 44.4, pp. 687-710.

Buiter, W. H., and E. Rahbari (2010), "Greece and the fiscal crisis in the Eurozone," Centre for Policy Research Paper, Policy Insight No. 51.

Cecchetti, S., and E. Kharroubi (2015), "Why does financial sector growth crowd out real economic growth?” BIS Working Papers, no. 490, dated February.

Cesa-Bianchi, A., J. Imbs, and J. Saleheen (2015), "Finance and Synchronization," CEPR Discussion Paper No. DP11037. 
Christiano, L. J., and T. J. Fitzgerald (2003), “The band-pass filter," International Economic Review, Vol. 44, No. 2, pp. 435-65.

Claessens, S., M. A. Kose and M. E. Terrones (2011), "How Do Business and Financial Cycles Interact?”, IMF Working Paper, No. 11/88, International Monetary Fund.

Comin, D., and M. Gertler (2006), "Medium-Term Business Cycles," American Economic Review, Vol. 96, No. 3, dated June, pp. 523-51.

De Grauwe, P., and Y. Ji (2016), "Synchronisation in business cycles: An endogenous explanation," VoxEU. Available at: http://voxeu.org/article/synchronisation-business-cycles.

De la Dehesa, G., and P.R. Krugman (1992), "EMU and the Regions," No. 39. Group of Thirty.

Decressin, J., and A. Fatas (1995), "Regional labor market dynamics in Europe," European Economic Review, Vol. 39, No. 9, pp. 1627-1655.

Dell'Ariccia, G., D. Igan, L. Laeven, and H. Tong, with B. Bakker and J. Vandenbussche (2012), "Policies for Macrofinancial Stability: How to Deal with Credit Booms," IMF Staff Discussion Note, No. 12/06, dated 7 June, International Monetary Fund.

Diaz del Hoyo, J.L., E. Dorrucci, F.F. Heinz, and S. Muzikarova (2017), "Real Convergence in the Euro Area: A Long-Term Perspective,", ECB Occasional Paper Series, No. 203, European Central Bank, dated December.

Drehmann, M., C. Borio, and K. Tsatsaronis (2012), "Characterising the financial cycle: Don't lose sight of the medium term!", BIS Working Papers, no. 380, dated June.

Eichengreen, B. (1991), "Is Europe an optimum currency area?", NBER Working Papers, No. 3579, National Bureau of Economic Research.

Emerson, M., D. Gros, A. Italianer, J. Pisani-Ferry and H. Reichenbach (1992), One Market, One Money: An Evaluation of the Potential Benefits and Costs of Forming an Economic and Monetary Union, Oxford; New York; Toronto and Melbourne Oxford University Press.

Enderlein, H., E. Letta et al. (2016), "Repair and Prepare: Growth and the Euro after Brexit," Gütersloh, Berlin, Paris: Bertelsmann Stiftung, Jacques Delors Institut - Berlin and Jacques Delors Institute in Paris. Available at: http://www.institutdelors.eu/media/repair-and-preparegrowth-and-the-euro-after-brexit.pdf?pdf=ok 
European Central Bank (2015), "Real convergence in the euro area: evidence, theory and policy implications,” ECB Economic Bulletin, Issue 5/2015, pp. 30-45.

European Commission (2013), "Building a Strengthened Fiscal Framework in the European Union: A Guide to the Stability and Growth Pact", Occasional Papers 150, Brussels.

European Commission (2016), "Quarterly Report on the Euro Area,” Vol. 14, No. 4 (2015), Special Edition, European Economy, Institutional Paper 016, dated January.

European Council, Committee for the Study of Economic and Monetary Union (1989), "Report on economic and monetary union in the European Community" (Delors Report), Unipub.

European Monetary Institute (1998), “Convergence Report: Report required by Article $109 \mathrm{j}$ of the Treaty establishing the European Community," dated March.

Eyraud, L., and T. Wu (2015), "Playing by the Rules: Reforming Fiscal Governance in Europe," IMF Working Paper, No. 15/67, International Monetary Fund, dated March.

Ferroni, Filippo, and Benjamin Klaus (2015), "Euro Area Busi-ness Cycles in Turbulent Times: Convergence or Decoupling?", ECB Working Paper Series, no. 1819, pp. 1-35.

Forgo, B., and A. Jevčák (2015), "Economic Convergence of Central and Eastern European EU Member States over the Last Decade," European Economy Discussion Paper, No. 001, dated July.

Frankel, J. A., and A.K. Rose (1997), "Is EMU more justifiable ex post than ex ante?", European Economic Review, Vol. 41, No. 3, 753-760.

Frankel, J. A., and A.K. Rose (1998), "The endogeneity of the optimum currency area criteria," The Economic Journal, Vol. 108, No. 449, pp. 1009-1025.

García-Santana, M., E. Moral-Benito, J. Prijoan-Mas, and R. Ramos (2016), “Growing like Spain: 1995-2007," CEPR Working Paper, No. 1609, Center for Economic Policy and Research.

Glick, R., and A. Rose (2015), "The currency union effect on trade: Redux," dated 15 June. Available at: http://voxeu.org/article/currency-union-effect-trade-redux.

Godley, W. (1992), "Maastricht and all that: Letter from Europe," London Review of Books, Vol. 14, No. 19: 3-4.

Gopinath, G., S. Kalemli-Ozcan, L. Karabarbounis, and C. Villegas-Sanchez (2015), "Capital Allocation and Productivity in South Europe," NBER Working Papers, No. 21453, National Bureau of Economic Research. 
Hamilton, J. D. (2016), "Why You Should Never Use the Hodrick-Prescott Filter," University of California, Working Paper.

Harding, D., and A. Pagan (2002), "A Comparison of two Business Cycle Dating Methods," Journal of Economic Dynamics and Control, Vol. 27, pp. 1681-690.

Hiebert P., I. Jaccard, Y. Schüler (2016), "Financial and business cycles across euro area countries: Close relatives or distant cousins?", Presentation at XI Annual Seminar On Risk, Financial Stability and Banking, Sao Paolo (August). Available at: http://www.bcb.gov.br/Pec/Depep/Seminarios/2016 XISemRiscosBCB/Ingl/archives/201604-HIEBERT-FC-Brazil-conference.pdf.

Huber, S. (2016), "Housing Booms and Busts: Convergence and Divergence in OECD Countries," Universitat Pompeu Fabra, mimeo.

International Monetary Fund (2011), "Regional Economic Outlook Europe: Strengthening the Recovery," World Economic and Financial Surveys, Washington, DC.

International Monetary Fund (2014), "Is It Time for an Infrastructure Push? The Macroeconomic Effects of Public Investment," World Economic Outlook, Chapter 3, October, Washington, DC.

International Monetary Fund (2016a), "Euro Area Policies: Staff Report for the 2016 Article IV Consultation," IMF Country Report, No. 16/219, Washington, DC.

International Monetary Fund (2016b), "Options for a Central Fiscal Capacity in the Euro Area," in "Euro Area Policies: Selected Issues," IMF Country Report, No. 16/220, Washington, DC.

International Monetary Fund (2017a), "Real Income Convergence in the Euro Area," in Euro Area Policies - Selected Issues, IMF Country Report 17/236.

International Monetary Fund (2017b), "Euro Area Policies: Staff Report for the 2017 Article IV Consultation," IMF Country Report, No. 17/235, Washington, DC.

International Monetary Fund (2017c), "Can Structural Reforms Foster Real Convergence in the Euro Area?," in Euro Area Policies - Selected Issues, IMF Country Report 17/236.

Jordà, Ò., M. Schularick and A. Taylor (2016a), "Sovereigns versus banks: credit, crises and consequences," Journal of the European Economic Association, No. 14, pp. 45-79.

Jordà, Ò., M. Schularick, and A. Taylor (2016b), "Macrofinancial History and the New Business Cycle Facts," in NBER Macroeconomics Annual 2016, Vol. 31, University of Chicago Press. 
Kaitala, V. (2014), "Transnational Income Convergence and National Income Disparity: Europe, 1960 2012," Journal of Economic Integration, Vol. 29, No. 2, dated June, pp. 343371.

McDermott, M., and A. Scott (2000), "Concordance in Business Cycles," IMF Working Papers, No. 00/37, International Monetary Fund.

Praet, P. (2014), "The Financial Cycle and Real Convergence," Speech at the Annual Hyman P. Minsky Conference on the State of the US and World Economies, Washington D.C., dated 10 April 2014. Available at:

https://www.ecb.europa.eu/press/key/date/2014/html/sp140410.en.html.

Rose, A. K. (2000), “One Money, One Market: Estimating the Effect of Common Currencies on Trade," Economic Policy, Vol. 15, No. 30, dated April, pp. 7-46.

Sala-i-Martin, X. (1996), "The Classical Approach to Convergence Analysis", Economic Journal, Vol. 106, No. 437, pp. 1019-1036.

Sala-i-Martin, X., and J. Sachs (1991), "Fiscal federalism and optimum currency areas: Evidence for Europe from the United States," NBER Working Papers, No. 3855, National Bureau of Economic Research.

Schüler, Y. S., P. Hiebert, T. A. Peltonen (2015), "Characterising the financial cycle: a multivariate and time-varying approach,” ECB Working Paper Series, No. 1846.

Stremmel, H. (2015), "Capturing the financial cycle in Europe," ECB Working Paper Series, No. 1811.

Stremmel, H., and B. Zsámboki (2015), “The relationship between structural and cyclical features of the EU financial sector," ECB Working Paper Series, No. 1812.

Sørensen, B., and O. Yosha (1998), "International risk sharing and European monetary unification," Journal of International Economics, No. 45, pp. 211-238.

Treichel, V. (2012), “The Euro crisis - What role did the common currency play?”, Let's Talk Development, dated July. Available at: http://blogs.worldbank.org/developmenttalk/theeuro-crisis-what-role-did-the-common-currency-play.

Tressel, T., S. Wang, J. S. Kang, and J. Shambaugh (2014), “Adjustment in Euro Area Deficit Countries: Progress, Challenges, and Policies," IMF Staff Discussion Note, No. 14/7, International Monetary Fund, dated July.

Wolff, G., and E. Vihiriälä. (2013), "Manufacturing as a source of growth for Southern Europe: opportunities and obstacles," Bruegel Blueprint XXI, "Manufacturing Europe's future," edited by Reinhilde Veugelers. 